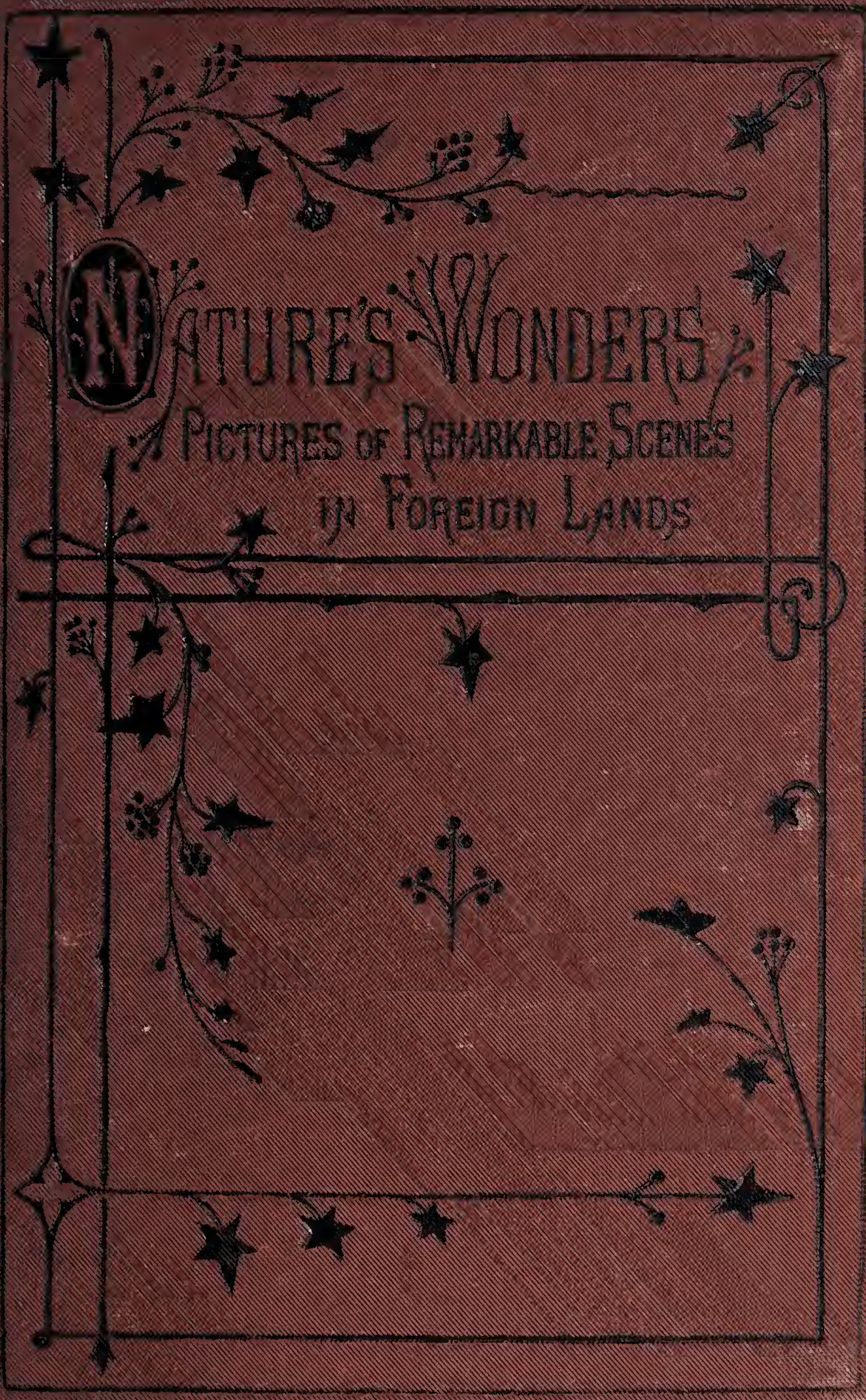




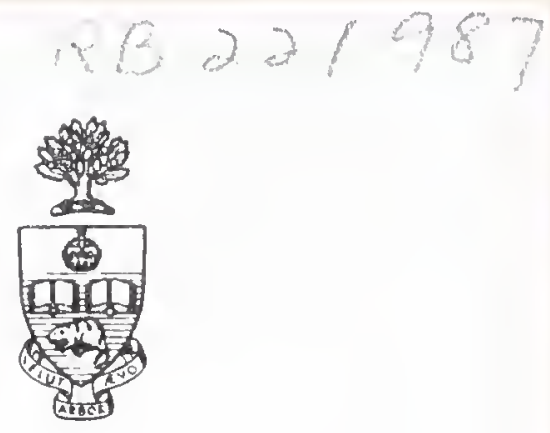

Presented to the

LIBRARY of the

UNIVERSITY OF TORONTO

by

The Estate of

Mark Seltzer 
Digitized by the Internet Archive in 2018 with funding from University of Toronto 


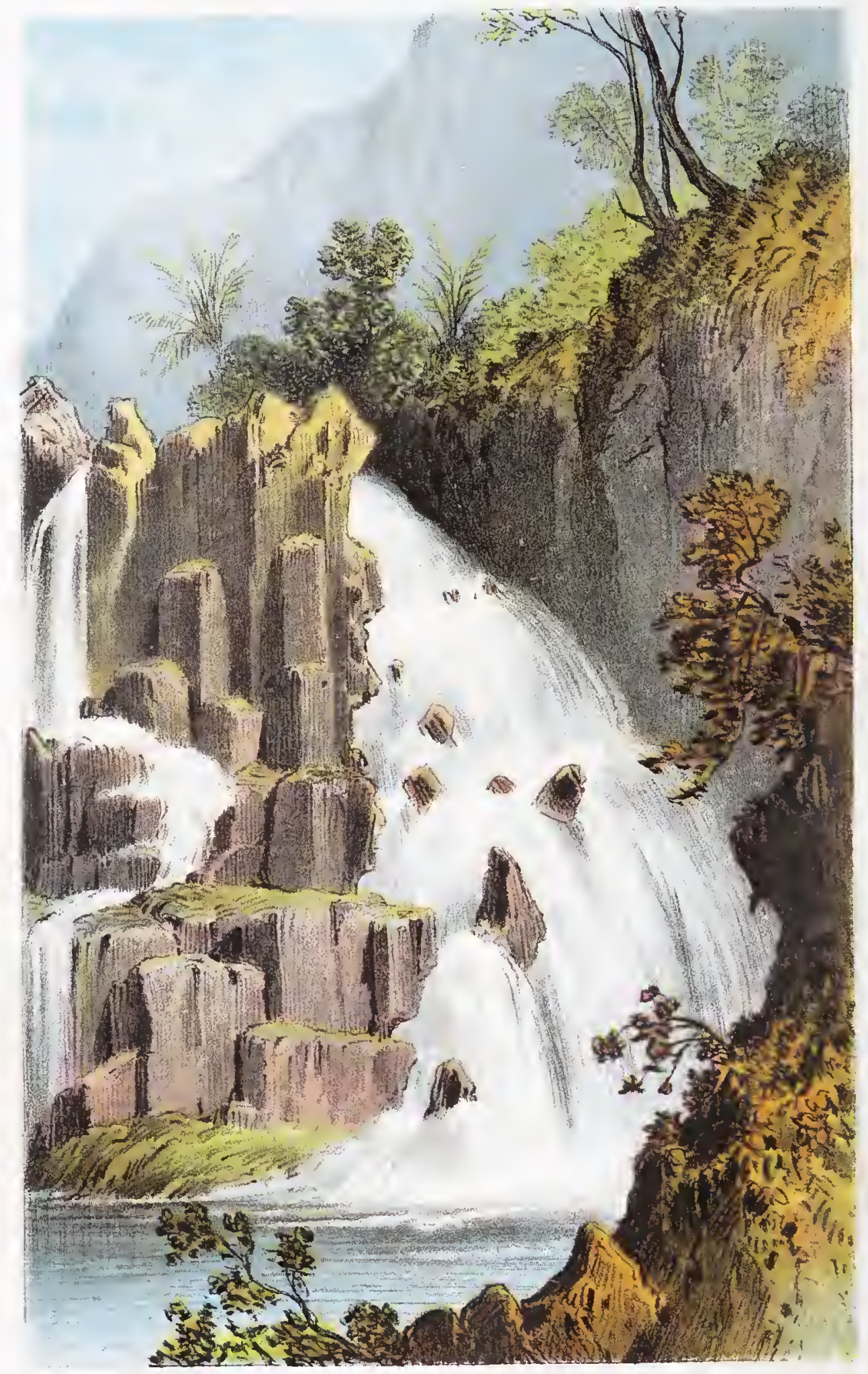




\section{NATURE'S WONDERS.}

\section{PICTURES OF REMARKABLE SCENES IN FOREIGN LANDS.}

\section{...." Of antres vast and deserts idle, \\ Rough quarries, rocks, and hills whose heads touch heaven,}

It was my hint to speak."

SHAKSPEARE.

\section{Teromdon:}

T. NELSON AND SONS, PATERNOSTER ROW. EDINBURGH; AND NEW YORK. 



\section{1) ictire.}

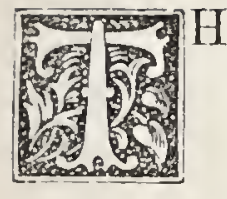

HE following brief sketches of a fer ontlying regions of the world will, we trust. prove not unacceptable to juvenile readers, and of some little avail in alding to the stores of juvenile knowledge. The regions described are all places of interest, have all been thought deserving of exploration, at risks, in many cases, which, to the explorer, were infinite; and have been pronounced worth all the discomfort and sacrifices undergone in visiting them. Many of them are spots which, from various causes, are capable of only temporary sojourn, and all are but rarely visited, and little known. Those who have seen them have thonght them worth describing to those who have not; and the interest which attaches to them, they and their readers feel to be a human one withal. Mere wastes, in most instances, of snow or sand, of solitude or darkness, they are not unconnected with liuman fortunes, and they make, both directly and indirectly, appeals to the 
liuman heart. 'The dreariest has liad a history and seen better days, though it now lies cold and dead; and forms a high-lying or out-lying, but integral, portion of those rock foundations which bear up the world and man's life. All the places described, however, are not, throughout at least, of this nature; but lie, some within the limits of possible, nay actual, existence, and a few even within the region of tropical life. But all these either verge on the former, or are of similar origin and conformation, though they are now clad with verdure and capable - of yielding shelter and sustenance to man. The products, as well as the aspects and workings of nature, in these regions, are more or less hinted at; and the sketches we have given are each accompanied by admirable woodcut illustrations, which faithfully exhibit features to a great extent physiognomic of the whole district.

J. W. 


\section{(aie outents.}

1. SCENES IN THE MAURITIUS: THE PETER BOTTE MOUNTAIN, ETC., $\quad \ldots \quad$.

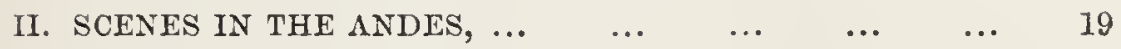

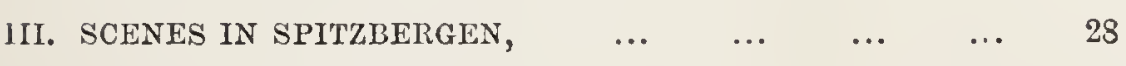

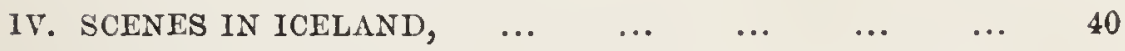

v. SCENES IN THE ALPS : MONT BLANC, $\ldots \quad \ldots \quad \ldots \quad \ldots 7$

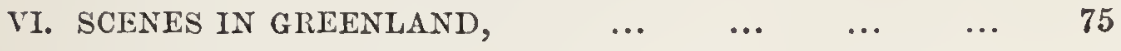

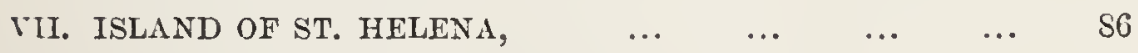

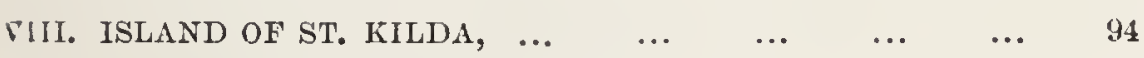

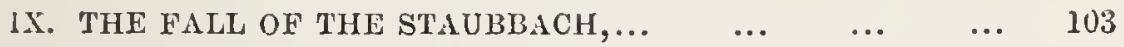

¿. THE GLACIER FOUN'TANS OF THE RHONE, $\ldots . \quad \ldots \quad 107$

XI. THE VALLEY OF GOLDAU, $\quad \ldots \quad \ldots \quad \ldots \quad \ldots \quad \ldots 15$ 



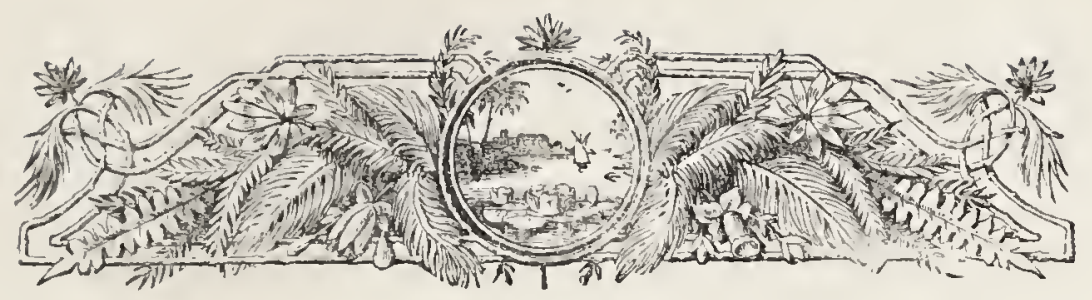

\section{NATURE'S WONDERS.}

\section{I.}

\section{Sencs in the attaunitus.}

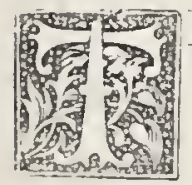

IIE Mauritius is an island of irregular oval shape, and exactly twice the size of the county of Edinburgh, situated in the Indian Ocean, 500 miles east of Madagascar, and about 200 miles within the southern verge of the Torrid Zone. Colonized by the Dutch in 16t4, and occupied afterwards by the French for nearly a century under the name of the Isle of France, it became a British possession in the year 1810 , which it has ever since continued to be. The English, at the same time, became masters of the Island of Bourbon, which is about 100 miles south-west, and a third larger; but, by treaty in 1814, while Mauritius was retained, Bourbon was restored to the French, to whom it still belongs. These two islands, though in such close proximity, are in many respects very dissimilar; Bourbon looking one huge mountain mass with 
several summits, one of which, called the Sugar-loaf of Snows, is 10,000 feet high, and another, said to be the most active volcano in the world-erupting twice a-year-is 7200 feet. There are wastes in it of mere ashes, lava and volcanic wreck, equalling, it is said, one-sixth of its area, and, though the rest is fertile, only one "quarter is under cultivation, while its climate is unhealthy to the last degree, and its shores dangerous, and often fatal, to shipping. The Mauritius, on the other hand, though not without abundant traces of volcanic agency, and covered with mountains, has none of its peaks so much as 3000 feet in height; and these, when seen from a distance, resemble a cock's comb. Approached nearer, the peaks look like fingers pointing heavenward, and are for most part feathered to their summits with treefoliage. The forms of the mountains are as beautiful as they are varied. Some present large vertical walls, others rise towering aloft in pyramids; some, as we have said, are covered to the top with thick wood, others only half way up, and these terminate in a point of rock, which shoots suddenly upward smooth and bare from a green ocean of foliage. They are cut up in all directions by lovely valleys, and steep, narrow gorges; the whole enveloped for most part in a rich, balmy atmosphere, and overlooked by a cloudless sky of the purest azure. The gorges and valleys are one and all, at certain seasons, swept by noisy torrents, which, when united, enter the sea by some twenty, or thirty, channels, or rivers. These rivers are frequently broken and enlivened by picturesque cascades-instance, those of the River 
Galets and Chamarel. The former of these, though of difficult and even dangerous approach-as most of them are-is, it seems, well worth all the risk run in reaching it. Formed by a river of the same name, it falls from a height of 600 feet over several groups of rocks of a ferruginous tint, which are covered with ferns and green soft moss-beds.

The soil of the island is of a red-rusty colour, from the presence of iron; so hard, when dry, that only a hatchet will break it; but when moistened by rain, viscid and tenacious, yet easily cultivated, and of the richest quality. It is covered throughout with often thickly scattered blocks of rock, or boulders, of a size varying from that of the human hand to that of masses of a ton weight; and these, too, are of a red colour, and composed, many of them, of earth arranged in layers like the coats of an onion. The ground under and around them is especially suited for the growth of sugar, which, accordingly, is the staple product, and of which as much as 65,000 tons was raised in 1847 alone. It is grown in the valleys, which, as we have said, are all well watered, and the cultivation of it occupies fully one quarter of the surface, and employs the majority of the inhabitants. The other crops the soil yields are chiefly wheat, maize, coffee, manioc, and yams; and, wherever it is not cultivated, the ground is covered with every variety of tropical tree, united together by a jungle of gay flowered creepers and climbers. These forests abound in palms, bananas, guavas, mangoes, and bread-fruit trees; and, here and there, is a species of tree fern, with beautifully long feathered 
fern-leaves growing in a mass from the top of a stem forty feet high, and depending in graceful curves to the ground. The tree in greatest repute for its timber is the ebony-tree; the heart-rood of which being hard, compacted, dark-coloured, and capable of a high polish, is extensively used for veneering, inlaid-work, and toys. As found in the Mauritius, the bark is white, the leaves large and thick, green on the upper surface, and white below, the flower smelling like cloves, the fresh wood of a fetid odour, and only the hard heart-wood black and available as ebony.

'The for'ests, and indeed the whole istand, swarm, as usual in these latitudes, with insects and reptiles; but meither here nor in Bourbon is there a venomous serpent to be found. Of the insects the musquito is the most troublesome, and, next to it, a creature called the flying-bug, which both "stinks and stings," and is a perpetual irritation in the cool of the erening. Scorpions and lizards exist in plenty, and landcrabs living in warrens and occupying holes like rabbits. In Drake's voyage, they are represented as " so large that one of them will plentifully dine four" persons." Acutely sensitive to light and odour, they are said to be dear as door-posts, and not to hear the report of a rifle, or feel the eartl shake when a bullet lights among them. A lizard there is, too, of fly-catching propensity, which, being provided with feet like those of the fly it hunts, can not only climb the walls of rooms, but crawl over the ceiling as well. Innocent, very agreeable companions, their persons are held sacred in most families for the flies and insects 
they abolish; only, in their eagerness to catch their prey, they sometimes, when on the ceiling, forget where they are walking, lose their footing, and fall amongst the company. There is no great variety of birds on the island; and though a few of them, like the cardinal, as he is called from the flashing scarlet he wears, are bright feathered, hardly any of them are gifted with a talent for singing. The only one that makes any respectable attempt in this way, is a bird they call the martin, who is a universal favourite, being "the life and spirit of the island, where all other birds are as good as songless," but his exuberance of spirits is often such that he will "break off with a laugh in the midst of the performance." The early Dutch settlers had at one time nearly exterminated his race, having mistaken him for an enemy who only devoured their fruit; but when they discovered, which happily they did in time, that by killing insects he saved more than he consumed, the exterminating war they had begun against him ceased, and they proceeded to treat him with the same religious regard in which, for a like reason, they hold the stork at home. Not so favourably could these settlers be made to think of another bird, called the dodo, a native of this island; for him they persecuted so relentlessly that he has not only never been seen there since, but his race has perished from the face of the earth, and all that remains of him in the museums of the world, for science to study, are a single head and two feet. Descriptions of the bird exist; and these represent him as of the most ungainly form and movement, with short scale-clad 
legs, large head and bill, short, sparse-feathered wings, a curly tufted tail, and of a size a little larger than a swan. The Dutch, though they used his flesh for food, took a mortal dislike to him, calling him "Disgusting-fowl;" and as from his slow movements he was an easy prey, they never rested till they cleared the island of him, and, as we say, it happened, the world. $\mathrm{He}$ is understood to have belonged to the cassowary, or ostrich, class of birds, and to have served some not undivine purpose in his day and generation, which it is to be hoped other creatures remain to fulfil. Parrots there are none native to the island, but paroquets, and an insignificant kind of monkey, who has mind enough, however, to combine with his fellows in plundering incursions upon man's estate, making off with his booty by snatching it up and pitching it to an accomplice outside in waiting, who, in turn, hands it to a third, and he to a fourth, until, at length, the prize is safely lodged in some retreat accessible only to monkeyhood.

In this island there are properly only two seasons; the one when there is a constant wind from the south-east, which is cool, and injurious to vegetation and fruit exposed to it; and the other, in which it blows steadily from the north-east, when the most delicious evenings compensate for the heat by day-November, December, and January being the hottest months in the year. The island is very much encircled by coral-reefs, and being subject, as all tropical countries are, to violent storms, is safely accessible only by a rock-and-fortress-protected inlet on the north-west. This is Port Louis, which is also 
the capital, and, like most other places, it retains the name given it by the French. Batteries. planted to

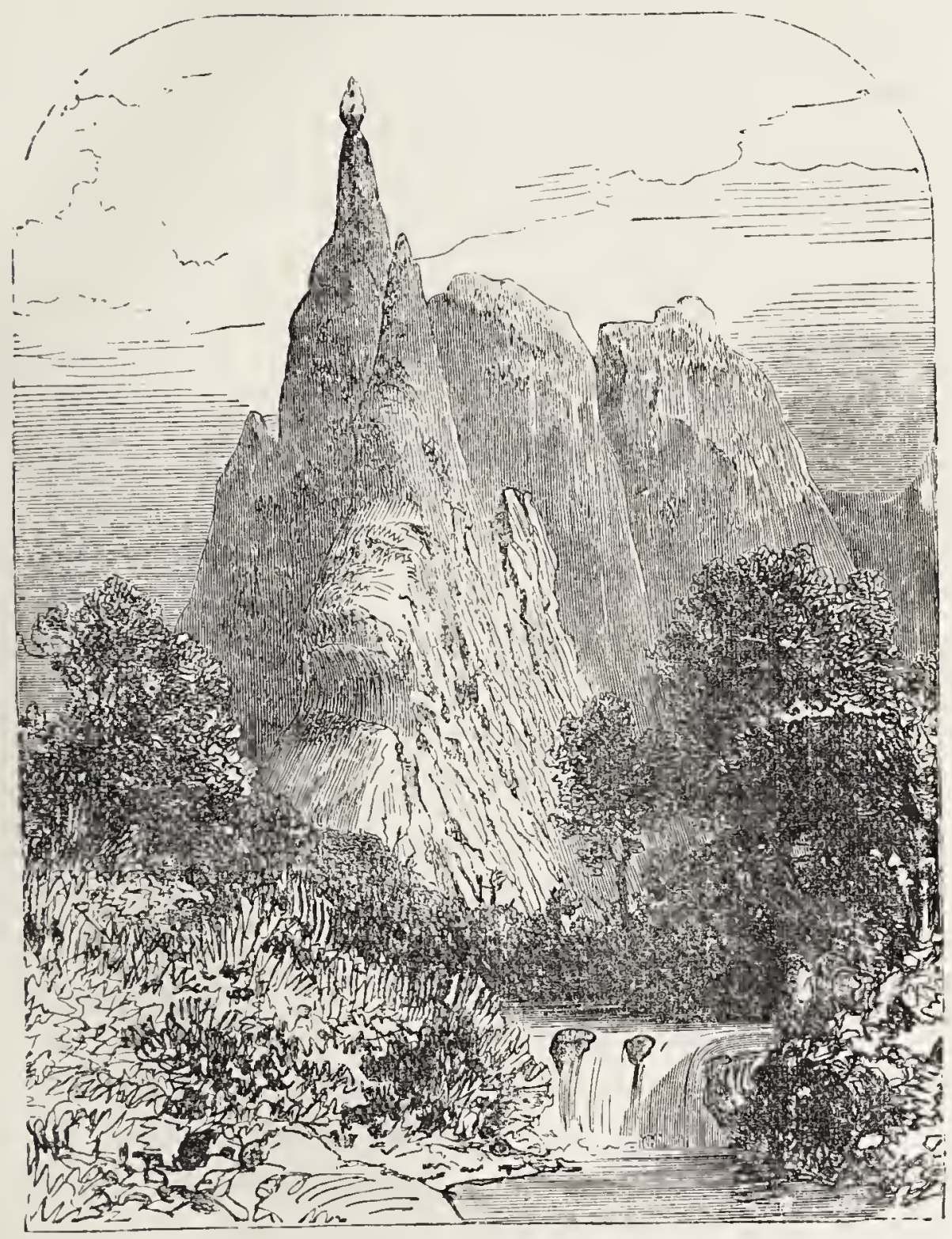

PELER BOTTE MOUNTAIN,

right and left, were once, if not still, strong enongh to defy ships of war passing in; and the port itself, intn which the pilot guides the versel with his eye 
upon the peak of Peter Botte Mountain in the rear of it, is "nestled" - an eye-witness assures us-_" at the foot of an amphitheatre of rugged, oddly-shaped mountains, in the centre of which rises the 'Pouce,' or 'Thumb,' covered witl wood to its very top."

The "Peter Botte," which is the beacon inwards, lies over the first range of hills to the left, and is not unworthy to rank among the wonders of the world. It is a mountain-pinnacle, which, seen from a distance, resembles, says one, a finger with a marble balanced on the tip of it; or, as others aver, the statue of a woman. At a nearer view, it is seen to be an obelisk, towering sheer up more than 300 feet from its base, and about 1800 from the plain, which, on one side, it overhangs, and surmounted by a huge irregular mass of detached rock. It owes its name to a Dutchman who, some say, succeeded in ascending it, but lost his life either at the last, or when he was descending, earning for his failure from an unsympathizing public no nobler distinction than that of "Botte" or "Silly." His fate, real or imaginary, did not, however, deter others from projecting, and even attempting, the same feat; and it was actually accomplished by a party of British officers on the 7th September 1832. This party consisted of four, and was attended by a number of sepoys and negroes, who carried for them the necessary block and tackle and provisions. The ascent was steep and toilsome from the very first, but the real difficulty lay in scaling the needle and surmounting the loose block at the top. The needle, which, at its base, on one side, rises 1800 feet sheer up from the plain 
below, was ascended by a negro, who, with a cord round his waist, and using his feet monkey-wise, clanbered up the knife-like edge, or ridge of it, on all fours. Attached to the end of the cord he carried was a rope, which, when he reached the neck, he hoisted and fastened, and by the aid of it the officers were, though not without difficulty, landed at his side. The detached block, still to climb, they found to be an immense mass, 35 feet in height, and projecting beyond its base many feet on every side; and the landing overhung by it to be a tolerably level ledge six feet wide, rumning about three-fourths round, and bounded everywhere, at the verge, by the abrupt edge of the precipice, except towards the perpendicular ridge, along which the ascent had been made. The block above, too, projected beyond the outer verge of the ledge all round, except here, and even from this point the eye as it glanced upwards could only see along its face. To adjust a ladder against this, therefore, was clearly impossible, nor could they by any projectile apparatus throw a cord orer to hoist one up. It was a puzzling, seemingly insolvable problem, but sailor intrepidity and ready wit soon and successfully resolved it. Captain Lloyd, one of the party, undertook to throw a line over, if his comrades would support him by a rope round his waist, while he swung himself horizontally back with his face looking upward and his feet planted against the perpendicular rock of the needle. It was a daring project, and frightfully perilous to all concerned, but it was at once adopted, and at length crnwned with complete success-not, however, till, 
after repeated failures, it was all but given up, when the stone, which frequently returned, was carried over aided by a wind that chanced. This was eagerly caught, as it descended, at the opposite side, and soon the ladders were raised, and our four adventurers, led by Lloyd screeching and hallooing, stood waving wildly the Union Jack at the top. This signal was at once recognized by thousands of onlookers on the watch in the port, and responded to by a salute from a British frigate in the harbour, and the guns of a battery in one of the forts. The fearless madcaps, having got a bottle of wine, christened the peak King William's, and drunk His Majesty's health, with hands round the Jack now planted by the flagstaff in the rock, and amid "hip, hip, hurrah." Here they by-and-by dined together, and after spending upon it an evening of glorious beauty, they descended in the morning, "stiff, cold, and hungry, leaving the Union Jack well secured, flying on the summit."

Mauritius is the scene of the story of Paul and Virginia, which was written on the eve of the French Revolution, and while the island was still subject to France. Faithfully has the author, Saint Pierre, who visited the island, delineated its beauties, and many are the objects associated with his morbidlythought, though musically-rendered, tale. Here it was, or rather amid imagination of scenes like these, that, according to Mr. Carlyle, "old France" chose to sing her "swan-song" and give up the ghost, longing for communion with Nature, and yet clinging to "diseased perfidious Art," pining for reality 341) 
and unable to enjoy it because it was not Frenchdying of "etiquette," and drawing tears of sympathy from all hearts. Two children, a boy and a girl, grew up from infancy together in this charming region, innocent and happy as the first pair in Eden; their fathers dead, but their mothers, who live together as sisters there, caring each for both as if they were her own. The boy, however, is of no birth, while the girl has high connections, who, when love emerges, induce her with consent of her mother to return to fortune and honour in ancestral France. She leaves her lover, vowing fidelity, and, through many temptations remaining true to her promise, is sent back. But when she returns, a storm overtakes the vessel just at the landing, and she alone of all on board is shipwrecked, choosing rather to perish than be saved at the expense of sacrificing the fine ladyism she had learned in France.

The southern part of the island is cliarmingly beautiful, especially the district called La Savane. It is remarkable for a cascade, which is nearly unique among waterfalls, for bursting over a precipice of upright basaltic pillars. This precipice is a thick wall of black basalt, composed of columns shaped into regular geometric prisms, as if they had been cut according to square and rule by the hand of man, and which are tightly packed together side by side like the cells of a honey-comb. The water in falling over them is dashed back from the tops of the shorter and broken columns in front, and leaps, when in flood especially, in a vapour of spray into a deep pool surrounded with water-lilies. The leaves of these lilies float on (341) 
the water without being wet, and the rain which falls upon them from the cascade collects on their surface into little dancing globules, as of mercury, while athwart their violet stems, which hang gracefully over the water, may be seen darting to and fro swarms of bright glancing, variously coloured little fishes. The environs of the fall are adorned with bananas and other tropical trees, which, along with the fresh feeling from the water, impart to the spot an air and aspect truly charming. Here the Cascade de la Savane at one season trickles gently, and at another dashes in spray, outmatched in its basaltic character only by the Cascade of Regla in the New World.

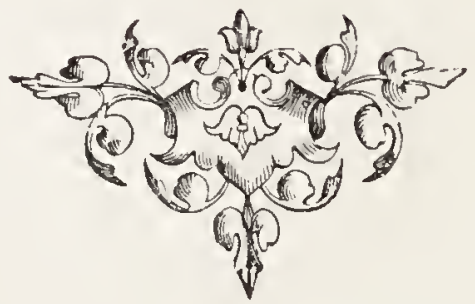




\section{II. \\ Sines in the Andes:}

CHIMBORAZO, COTOPAXI, AND NATURAI BRIDGE

OF ICONONZO.

1. WIMBORAZO, though not the highest mountain in the New World, as it was long thought to be, has been ascended higher up by man than any other in either hemisphere, if we except the peak of Ibi-Gamin, in the chain of the Himalaya,-Humboldt, in 1802, having attained an elevation of about 19,000 feet, and Boussingault, thirty years after, a height of 20,000 feet. This mountain is 21,420 feet, or fully four miles high, and situated not far south of the line in Ecuador, South America. It was on the 22nd of June, Humboldt, with his friend Bonpland and a number of native guides, commenced the ascent, and after halting for the night at the Indian village of Calpi, far up the sides of the mountain, he and his companions started for the summit on the morning of the 23rd. This summit is approached all round by a succession of level terraces, called Ilanos, covered with vegetation, and rising, the highest of them, to an elevation greater than the peak of Teneriffe. These llanos, which are perfectly horizontal, re- 
semble the bed of what had once been a lake, and forcibly recall the steppes of Central Asia, while the mean temperature is the same as that of Paris. At an elevation of about 14.000 , or 15,000 feet, the vegetation ceases, and only rocks appear, rising aloft from fields or slopes of eternal snow, and resembling at times, in the distance, forests of trees, dead indeed, but still standing. Undertaken from the south-west, Humboldt found the ascent possible only along one of the ridges, owing to the depth and softness of the snow which had recently fallen on the slopes; and this, as he proceeded, became always narrower and steeper, until at length all the guides refused to advance further, and he and Bonpland were left with only one attendant to prosecute the rest of the way alone. In this they made greater progress, in spite of the mists, than they expected; but it was amid dangers which thickened at every step. The ridge, or back of the knife, as the Spaniards call it, along which they ascended, was often hardly a foot in breadth, while to the left there sloped away a field of snow at an angle of thirty degrees, coated with ice glancing dazzlingly like a mirror; and on the right, the eye looked dcwn into an abyss 900 feet deep, into which there was the danger of falling and being empaled on rock-needles. "We proceeded," says Humboldt, "with the body inchined, however, more to the right-the danger on the left appearing greater, because there were no rocks to cling to in the event of slipping over, and there was the risk of sinking through the ice, which coated the surface, and being buried in the snow." 


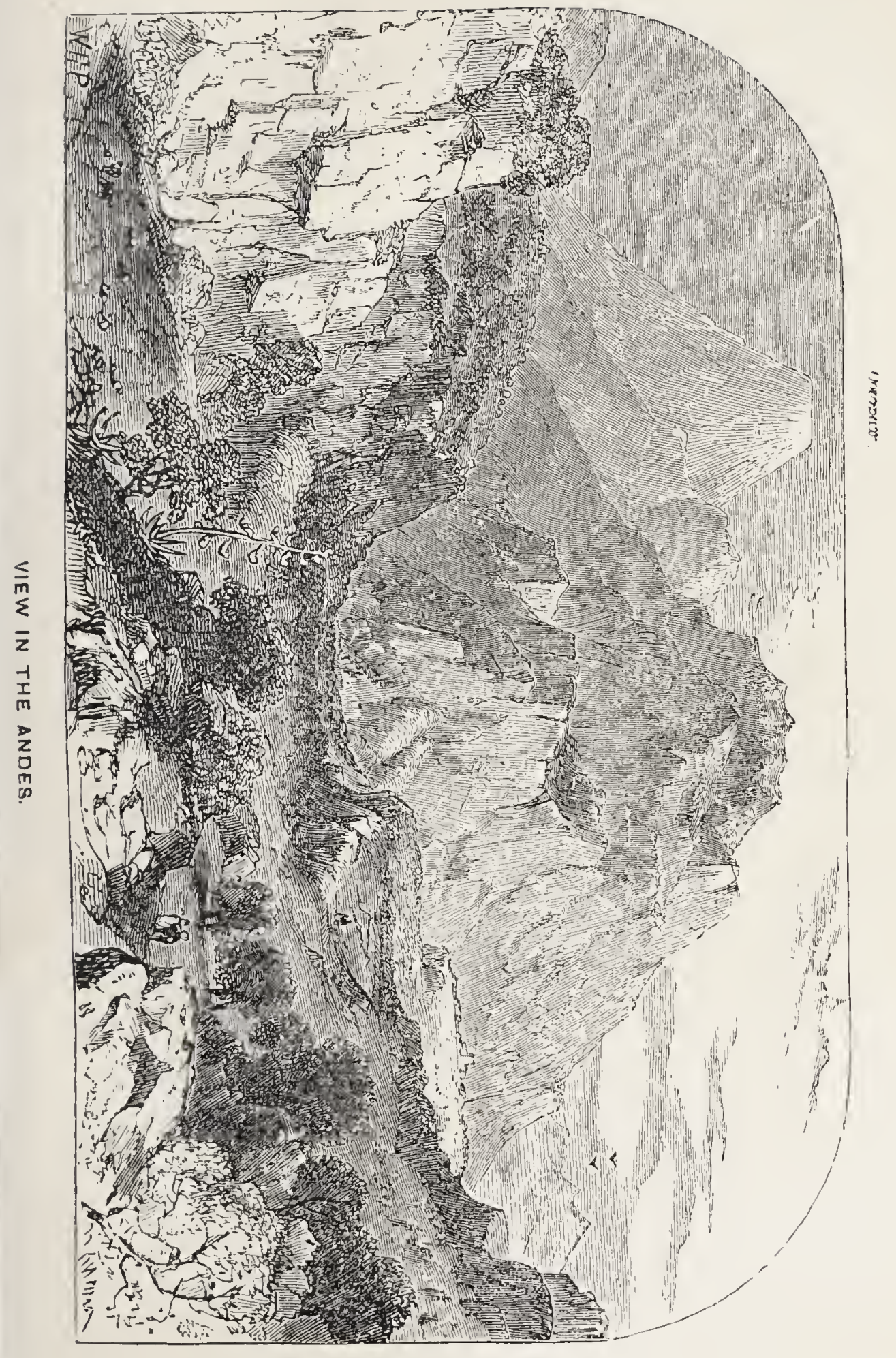



At length the ascent became more difficult still; the rocks more crumbling, the slope so steep that it was necessary to employ hands as well as feet, and there was the risk every moment of being wounded by the sharp asperities of the rock. Nay, not unfrequently were the rocks, which they might be tempted to use for props, found, on trial, to be such as would certainly have given way had they trusted to them. Here the temperature was five or six degrees below freezing, the ground humid, and the mist obscuring. The party, too, began to experience vertigo and an inclination to vomit, and in this the native, who accompanied them, was the greatest sufferer. The eyes grew blood-shot, and the gums and lips began to swell and bleed. The same effects Saussure experienced in his ascent of Mont Blanc; but, what is curious, they began to show themselves with him at little more than half the elevation. This depends partly on the air and partly on the individual. Gay-Iussac ascended in a balloon to a greater height than any mountain-explorer, without being subjected to one half the inconveniences. And now the veil of mist, which had hitherto enveloped the party and the top of the mountain, suddenly cleared away, and the rounded, dome-like summit appeared close at hand. The way, too, began to widen, and the confidence of our travellers to increase; but before long a barrier confronted them, and this, though the summit beckoned them upward, they found it impossible to surmount. This was a crevasse that yawned athwart the ridge more than 400 feet deep and 60 feet wide. The ridge, or 
rather ledge, indeed, prolonged itself beyond, but to attempt to reach by descending the chasm, appeared an enterprise too perilous, and there was nothing for it but to stop short. It was the utmost elevation yet attained on the globe by human beings, though they were still 1500 feet from the top. Here it was impossible to remain long, for the mist re-descended, and there was a good distance to retrace to find a shelter to pass the night. Snow also began to fall; but in two hours the party had got back as far as the guides and their horses which had been left below the snow-line.

Chimborazo is an extinct volcano, yet is the volcanic force not quite extinct in its depths, for though the natives pay no heed to them, earthquakes aie not uncommon on its slopes and around its base. Cotopaxi, its neighbour, which Humboldt also attempted, is still in action to its very summit, and at times erupts with a noise which is heard 700 miles off, and a torrent of flame which ascends 3000 feet above its crater, and this, though the mountain itself is 2500 feet higher than Vesuvius piled on the peak of Teneriffe. The rocks and scoriæ ejected by it would, if collected from its slopes and gorges, form a mountain of imposing proportions. Its summit is a perfect cone 4000 feet high, covered all the way down with snow of a dazzling splendour, particularly at sunset, but which disappears on the eve of an eruption, and isolated from the rest of the mountains by deep ravines which defy all attempts to reach the top. This top, seen at a distance, looks a parapet of bare rock, which surrounds the crater like 


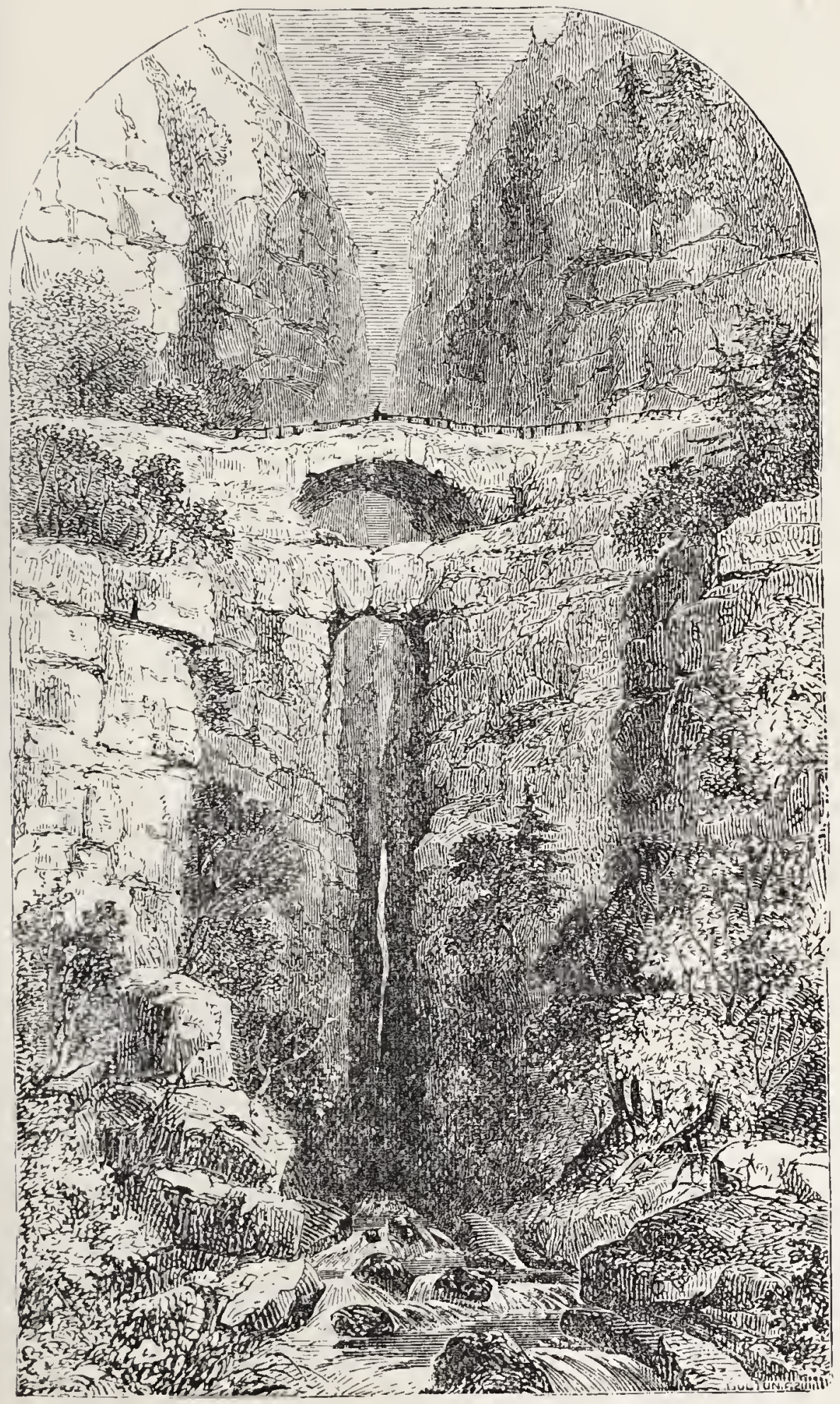

NATURAL BRIDGE OF ICONONZO. 

the fumnel of Teneriffe; and, in this respect, Cotopaxi differs from Chimborazo, which terminates in a dome.

The valleys in the neighbourhood of these mountains are generally crevices, often of enormous depth, and some of them, which are narrow, are united and arched over by natural bridges formed of fallen rock. The most remarkable of these bridges are at Icononzo, south of Santa Fé, and one of them is especially remarkable for the singular forms of its rocks, "the naked tops of which," according to Humboldt, "present the most picturesque contrast with the tufts of trees and slirubs which cover the edges of the gulf." This arch is 47 feet long, 39 feet broad, and the fissure it bridges over is 318 feet deep, while the bottom of this fissure is swept by a stream that comes rushing and foaming into it after a fall in the form of a double cascade. Sixty-four feet lower down is another bridge "composed of three enormous masses of rock, which have fallen so as to support each other. In the middle of this arch is a hole through which the bottom of the cleft is seen. The torrent, viewed from this place, seemed to flow through a dark cavern, from which a doleful sound arose, emitted by the nocturnal birds that haunt the abyss, thousands of which were seen flying over the surface of the water," supposed by Humboldt, who reports this, "to be goatsuckers."

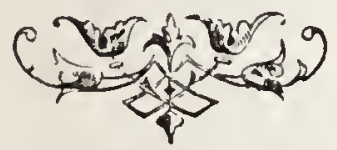




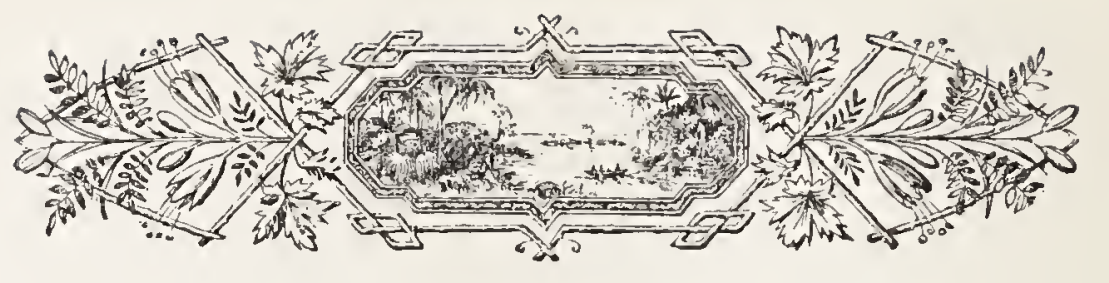

III.

Stures in Spitzbormor.

PITZBERGEN forms a cluster of islands which lie nearly due north from the North Cape, and are at their northern extremity 2000 miles from London, and rather more than 600 miles from the Pole. They are composed of primitive rock, covered with sharp-ridged and many-peaked mountains, and indented all round with deep bays or fiords, which, with the valleys at their head, are more or less completely occupied by enormous glaciers. They form the most northern land yet discovered upon the globe; and, with the exception of Captain Parry in 1827, no navigator is known to have even sailed beyond them. Even he, though he ventured farther, with only boats and sledges, had to retire after he had ascended only 100 miles farther north, having found that he was being carried southwards by the ice-floes at a greater rate than he was advancing up.

Spitzbergen was discovered by a Dutch sailor in 1596, and was subsequently visited by Hudson, among others, in pursuance of a project, then popular, of approaching the east by the North Pole. It was not an unfrequent resort for whalers after this, 
of whose visits traces are stiil visible in the coffined dead they left unburied behind them; but, ever since the fisheries to the east of Greenland have been abandoned for those in Baffin's Bay and Davis' Straits, Spitzbergen, as being off the route, has been rarely trodden by the foot, and hardly so much as seen by the eye, of the sailor. Since then the few who have visited it lave done so for purposes of science or adventure; and of these the most distinguished are Dr. Scoresby and Lord Dufferin.

The latter visited it in the August of 1856, but could not, for fear of being locked in by the ice, remain longer than five days, having arrived at one A.M. of the 6th, and departed at three p.s. of the 11 th. He sailed in a schooner called the Foam, manned and equipped for the occasion, and approached the island from the south, through fogs and seas of floating ice, by, after sighting it, coasting the icebarrier to south of it westward, then turning north, and finally coming down upon it from the north-west. He took a western course to find a northern opening through this barrier, because he calculated he would be aided by the Gulf Stream, which, consisting of a river of heated water from the tropics, was known to flow north to west, and not to east, of the island. Seen at a distance for the first time to the nortleast, by a sudden clearing up of the atmosphere, it seemed a forest of peaks glittering "gem-like," and this view justified at once the name it went underSpitzbergen; that is, mountain-land of peaks. Approached nearer, it unfolded into sharp-ridged and needle-peaked ranges of hills of "gneiss and mica 
slate" terminating sea-ward, and including valleys covered throughout with immense fields of ice, which extend into, and end precipitously in, the sea.

The bay into which the Foam steered, and where she for the five days of her stay there lay at anchor, is called the English Bay, and is understood to be one of only two inlets in which ressels at that season might be reckoned safe against being blucked up for the winter by the drifting ice. It is a "silent haven" and "completely land-locked," being defende as it opens westward by the foreland of an island which stretches opposite it north and south. As the ship on this occasion dropped anchor in it, all seemed still and solitary as an abode of death. There was no sound or sign of life, or living thing, in the air above, on the land adjoining, or even in the water round, except it were the far-off booming from time to time of what it seems was the plunging of large ice-masses from the brow of the ice-cliffs into the silent sea. The sun even hung over the horizon to northward "muffled" in a death-like mist, and shedding on the scene a weird light, in keeping with the general ghastliness. Mere sea, naked rocks, and expanses of ice, occupied the whole landscape. The bay itself is nearly filled by a glacier, which is thought to extend inland above 30 miles, and the portion not so filled is formed on its east side by the sea-ward cliff of this glacier, 120 feet high, and by two sharpridged ranges which bound it - the one to north and the other to south — and jut farther into the sea, six or eight miles apart. This glacier is not the largest in the island, which is full of them; for there are others 

said to be 50 miles long, 10 miles broad, and 500 feet in height, where they beetle over the water, but all of them, as is common, seem to topple, and as if, with the slightest agitation, they would precipitate their whole mass downward into the sea. Such was the bay in which Lord Dufferin and his company moored their vessel for the five days they spent in Spitzbergen. Soon after the ship was brought to anchor in this haven, all on board were, from sheer exhaustion, buried in a slumber nearly as profound as that which reigned in Nature round them. The ice-falls from the brows of the cliffs which terminate the glaciers, as they tumbled over into the deep sea overhung by them, alone disturbed the death-like silence, and the only variation in the sound which broke upon the ear of the sleepers was due to the nearer or remoter distance of the falling masses. These masses were of all sizes, and Dr. Scoresby bears witness to having seen one descend a height of 400 feet into the water "as large as a cathedral!" When they have fallen, they float away, covering the sea in these parts in all directions; and, being fresh, when they melt, they cause the water of the Polar regions to be less brackish than that of more southern latitudes.

As the morning advanced, the crew awoke from slumber, and, after breakfast, lowered the boat and pulled for the shore, to see what was to be seen, take photographs, and stalk deer. They landed on the north or left-hand side of the bay, as the only vegetation within ken appeared in that quarter, and this turned out to be a belt of black moss, half a mile in width. Here they soon assured themselves of the 
presence of the animal they had come in quest of, for they saw in several parts the marks of his hoofs; but though they scanned the horizon all round with telescopes, they could nowhere see a horn, or, indeed, any other creature, winged or wingless, at which to aim a shot. With the thermometer below freezing, they proceeded to explore northwards, and found the shores in that direction bestrewed all over with logs of driftwood, and here and there, alas! too, with planks of ships, and even bones of animals, borne thither evidently from other latitudes by the Gulf Stream,- - the last apparently on icebergs which had been wrecked there. But what surprised them most was the discovery of an open coffin surmounted by a wooden cross, in which there lay extended the skeleton of a Danish seaman, who, as an inscription testified, had been left there by his comrades 100 years before. This coffin could not, it seems, have been buried underground, as, the soil, such as it is, being always frozen there at two inches from the surface, it is impossible to dig a grave. Other sailors who visited this region have, it is said, fallen upon the bodies of men that had died in these latitudes 250 years before, but which, having been deposited there, had become and remained so incrusted with ice, and been thereby so preserved from corruption, that their features could be completely discerned by pouring upon their faces boiling water.

No trace of vegetation did our adventurers find except the black moss already mentioned, and this, they noted, never grew beyond twenty feet above the sealevel. Though of sailor race and habits, none of 
them appears to have attempted either the ridges or peaks of the mountains. To have reached Spitzbergen itself, was feat enough without attempting more; and there, where they could safely foot it, the practical sense within them appears to lave told them they had reached a limit, by transcending which they could experience and know little more. Many who had already made the attempt had lost their lives in making it; and Dr. Scoresby, who by miracle, as it were, succeeded, had reported nothing to tempt Lord Dufferin to repeat the experiment. "Bay to north and south of you, like the one you anchor in, filled with glaciers of larger dimensions and still more sea-invading; sea of glass to westward; mountains with innumerable peaks to east, far as the eye reaches; cloudless canopy of azure overhead; the whole lit up by the glory of a blazing sun; sublimity of the spectacle enhanced by the perilous situation of the beholder, as he straddles on a ridge too narrow for human foot-sole." Such was what Dr. Scoresby witnessed; and this spectacle was one our heroes had no ambition to observe again. From a less dangerous elevation, the whole as it lay around with its needles of stone, it was privilege and honour enough to them to have seen, looking up to it, and they had no very ardent wish to command it all by looking down.

The sun, which never set while they stayed on the island, they report as being brighter at midnight than at noon, and they were successful in photographing here and there an object by its midnight light. The frost at night was so intense as to mantle the 
bay all over with a thin coating of ice one-eighth of an inch in thickness, which looked like oil, and would rise and fall with the undulation of the water without breaking. In winter the cold in these regions must be something frightful, when in summer the thermometer descends so low, and the mists, as well as seas, are daily frozen. Wintering on the island has, indeed, been attempted, but with fatal issues for most part, unless with infinite precautions, - the demon to guard against being cold, not scurvy, and those who have perished under it, having, from the contortions visible, died in agony. "No description," says Lord Dufferin, "can give an adequate idea of the intense rigour of a six month's winter in this part of the world. Stones crack with the noise of thunder; in a crowded hut the breath of its occupants will fall in flakes of snow; wine and spirits turn to ice; the snow burns like caustic; if iron touches the flesh it brings the skin away with it; the soles of your stockings may be burnt nff your feet before you feel the slightest warmth from the fire; linen taken out of boiling water, instantly stiffens to the consistency of a wooden board; al heated stones will not prevent the sheets of the bed from freezing. If these are the effects of the climate within an air-tight, fire-warmed, crowded hut, what must they be among the dark, storm-lashed mountain-peaks outside?"

Of animals his lordship did not see many, and he and his companions appear to have shot nearly all they saw, -one or two eider-ducks, as many ice-birds, sixteen ptarmigan, and one bear. With another creature the waters round swarmed in plenty, but 
it wore such a look of rationality and wise, human gravity, that our Englishmen, with their perennial reverence for "the heavenly in man," dared not touch it. This, it need not be mentioned, was the intelligent, gentle-hearted, and docile seal. "The ice-bird is the most graceful winged creature," says his lordship, "I have ever seen, with immensely long pinions, and plumage of spotless white." The eider duck is seen throughout the year on the northern shores of Scotland, and known in the winter months to frequent even the southern shores of England. It is valued chiefly for the down, which it plucks from its breast and spreads over its eggs when hatching; and collecting it from the nests at this season, or plucking it from the animal itself when dead, is the profitable occupation of many in the lower latitudes of these northern regions. The ptarmigan, the only other bird Lord Dufferin's people met with in Spitzbergen, is a small creature of the grouse species which has a curious affinity for spots of the same colour as its own body, by alighting upon which it becomes, as if by magic, all at once invisible. The first bird of this species, shot by these adventurers, was so small that the hole made in it by the rifle-bullet which killed it was as large as its own body! As for Bruin, the killing of him was quite a sensation, and Lord Dufferin himself had no merit in even assisting at the operation, for he was sighted and done for by the crew of the vessel while his lordship was at a distance on land shooting ptarmigan. At first, when he heard the firing, he dreaded a mutiny of his men on board the ship, but, 
as he hurried off from his shooting in the direction of the vessel, he was met by his servant, a man of melancholic temper, whom he had left near the shore taking photographs, who, as he now breasted the hill in the utmost excitement, and when he thought himself within earshot, stopped dead short, and making a speaking trumpet with his hands, shrieked, "If you please, my lord, there's a b-e-a-a-a-ar." His lordship instantly cocked his rifle, expecting to see the animal at his servant's heels, and hoping to roll him over should he appear in sight; but "what was my disappointment," he adds, "when, on looking towards the schooner, my eye caught sight of our three boats fastened in a row, and towing behind them a floating object, which my glass only too surely resolved the next minute into the dead bear." The skipper, it seems, noticed it when a full mile to westward making for the shore, and instantly gave the alarm to all on board; but it had to approach nearer before they could decide whether it was a bird, a whale, or a mermaid. As soon, however, as he was recognized, every rifle was levelled at him; and when they had tugged him home, raised him to the deck, and dissected him, his body was found perforated with six wounds, all mortal. The steward, to whom the honour was awarded of having lodged the bullet which had been actually fatal, was afterwards in honour decorated with the one which had been extracted from the gizzard. This bear when sliced into pieces did not prove such a god-send as his captors thought when they caught him; for the sailors, judging it indiscreet to eat of 
an animal, the offal of which being eaten, had nearly killed a favourite fox on shipboard, threw the whole bit by bit into the sea. The grease, however, the crew had thought more highly of, as his lordship inferred from the sleek appearance they presented for days after. Indeed, the steward's head and whiskers, we are assured, rivalled in polish Day and Martin, and might have served for a mirror whereat his lordship, or another, could have seen successfully to shave. Such sport can healthy Englishmen, when together, extract from poor, barren solitudes, but whoso wishes to understand how they managed to do so, must consult Lord Dufferin's own narrative, and be of British blood.

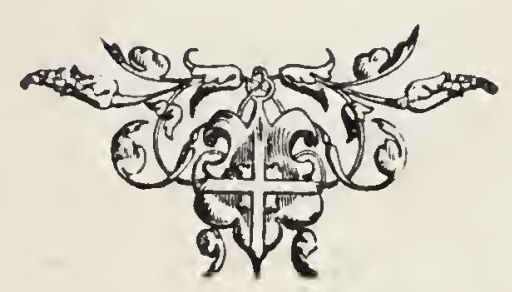




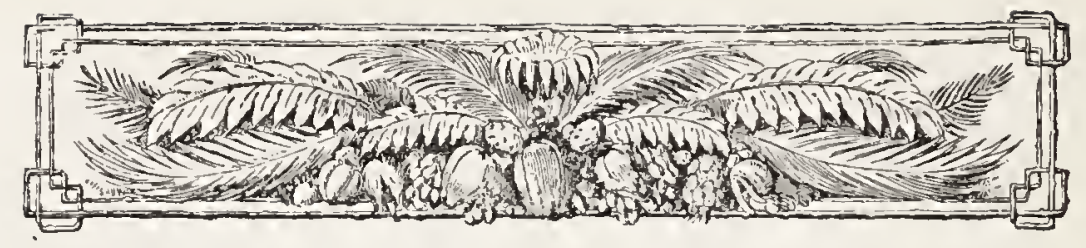

\section{IV. \\ Scrurs in allecland.}

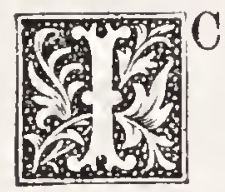

CELAND is an island one-fifth larger than Ireland, lying five hundred miles northwest of Scotland, and overlapping by ite northern margin the Arctic Zone. It has been known, by name at least, to the rest of Europe for a thousand years, having been discovered in 860 , and first colonized from Scandinavia in 874. By way of it, too, Europeans, a hundred and twenty years later, arrived on the shores of Greenland, and erelong America itself, five hundred years before its discovery to the rest of the world by Christopher Columbus in 1492. The first to approach it was a Norse pirate, or viking, who, in 860 , drifted near it, and, after sighting it, called it Snowland, and returned home. It was next visited by another Norseman, who, by way of taking formal possession, spent a season on it, sailed round it, and baptized it, after himself, Gardar's Holm. Floki, the third adventurer who left the shores of Europe to explore it, took with him three ravens for pilots, having at starting offered a solemn sacrifice to Thor, and was guided thither by the third raven, which, when let off, flew northward. Floki of the Ravens, as he is therefore 
called, stayed three years upon the island, and, after surveying its shores and river-banks, gave it the name it has ever since retained in history. He returned to Norway, representing its grass as dropping butter and its seas as swarming with fisli; and the report he brought was tempting enough to induce a number of his countrymen, who were oppressed at home, to choose it for their place of exile and free abode. These exiles, who sailed under Ingolf from Drontheim in open boats with a few sheep and cattle, landed and settled in Reykiavik, in the Fiord, on the south-west, which has ever since remained the capital-directed thither, as they construed, by the gods. They had carried with them the sacred pillars of the home they left in Norway, and having cast them into the sea, they took this spot, into which they drifted. for the one in which the gods had willed they should settle and dwell.

Men they were, it seems, of the best and bravest, who sought not gain, but freedom, and would rather die than be driven to do what, in their thinkings, misbeseemed a man. Such were the original settlers in Iceland, and of such stuff for three hundred years did their descendants prove themselves to be.

The land these Norsemen, thus inspired and guided, chose as their future home, for themselves and children, is one of the most remarkable on the face of the earth, and the least attractive of all the regions upon it selected and occupied as a dwellingplace by man. A strange land "burst up," as the geologists say, "by fire from the bottom of the sea;" largest surface and mass of territory in the world 
created solely by submarine rolcanic agency; "a wild land of barremness and lava, swallowed up many months of every year in black tempests; towering

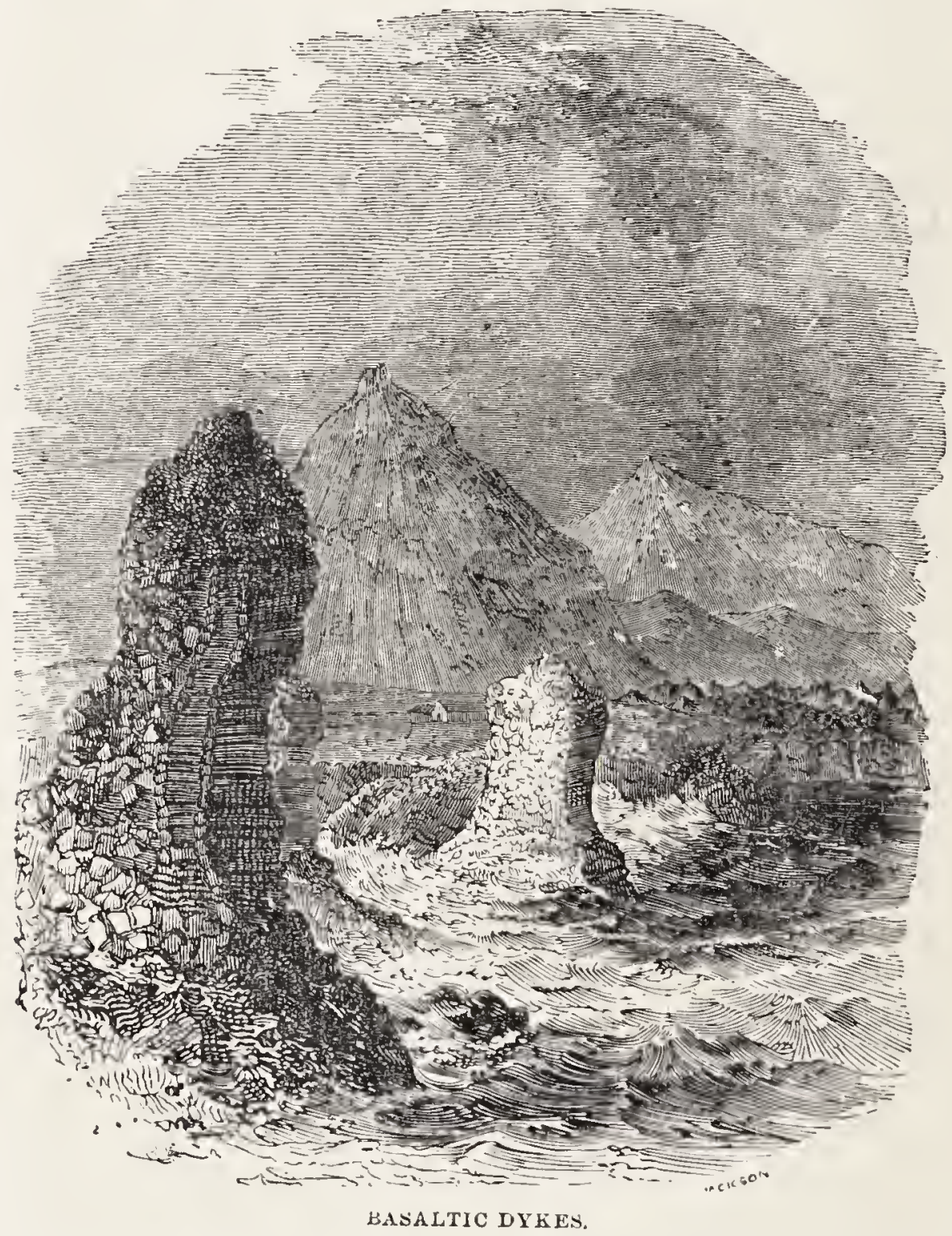

up there, stern and grim, in the North Ocean; with its snow-jökuls, roaring geysers, sulphur-pools, and horrid volcanic chasms, like the waste chaotic battlefield of Frost and Fire." It burst up from the 
bowels of the earth, thousands of years ago, a mass of lava, or molten earth-rock, and, cooling suddenly, cracked into hard irregular blocks of all shapes and sizes, through which, in after-years, poured tumbling other masses, until at length these, by ever and anon erupting at the summit, swelled into mountains, which, as they 'cooled, became gradually covered to a peak with ice and snow. Nor did its connection with the central fire cease with the epoch of its formation; it subsists to this hour, particularly along a belt of land of very varying breadth which stretches across the island from north-east to south-west, and is full of openings which, by their eruptions, testify to the continued action, at its very surface even, of the fire-agency which, at the first, projected it from the sea-depths. Risings and fallings there still are of lands at the sea-coast; steamings everywhere of vapour impregnated with sulphur and other minerals; caldrons of all sizes undulating here and there with water at all temperatures up to the boiling point; large basins with nether-communications, ejecting ever and anon with thunder noises, here high steaming columns of mineralized boiling water, and there dirty sputterings of mingled sulphur and mud; and to crown all, sleeping under the ice-mountains, are volcanoes which at any moment may open, scattering desolation over the island and darkening the sky to our own shores. Well called by Thomas Carlyle, "The waste chaotic battle-field of Frost and Fire." Nowhere else on the earth's surface are these two elements in such close proximity, or is their ancient feud kept up so fiercely to this day. 
This island, like Norway and the other islands of the North Ocean, is deeply indented with long narrow inlets called fiords; and these, in the case of Iceland, result from the lava having been thrown up from the central mass in divergent rays, the extremities of which still exhibit volcanic upheavals. These rays or promontories, which divide the fiords, are generally mere naked heaps of lava-blocks contorted into all shapes, and piled up in the wildest way, haunted, it may be, by sea-fowl, but without trace of tree or herb, grass or even moss-bed. Only as you retire up the fiords themselves do you come upon any vestige of vegetation, and this oftentimes of so dark a green that it seems as if it had been fished up from the bottom of the sea. On the banks of the rivers, which are numerous, and rise in the jökuls or glaciers which also abound, at a distance, in one case, of two hundred miles from the sea, there are, though nowhere else, grass meadows to be found, but the grass is generally of a coarse quality, and often mown and gathered under two or three feet of water. Grass of this nature, and moss, are to be met with a certain way up the valleys; but, though they speak of forests, nowhere are there any trees, these being only bushes never exceeding nine feet, and in most cases four or five in height. Grain there is none, nor possibility of any, for want of fit soil and season, and therefore no agriculture; while such pastures as there are yield a forage barely sufficient for the cattle kept by the natives., The ponies, which abound, running wild, and are the surest-footed animals of the kind-such that Lord Dufferin assures us specimens are to be had 
which can, without a slip, go down-stairs backwards --are left through the winter to forage for themselves, and are usually so emaciated in spring that it is June before they can be fed up into faculty for anything. It is a country of bald rock, volcanic wreck, and ice, for most part, on which man, isolated from Europe, could not survive a generation. Fish, fowl, and flesh occasionally, are at the option of the natives, but no grain, except a form of rye or grass, which, though the seeds of it can be ground into meal for making cakes or pottage, grows too scantily to supply the lack of the ordinary cereals, or graincrops. As it is, there are families which, by exchange even, can hardly procure wheaten bread enough for their households, to supply a meal once a week. In some cases, so hard bestead are they for fuel in winter, that they have to warm their huts by burning carcasses of birds which have been laid up for food. Sea-birds abound, such as eider-ducks and land-fowl, in plentiful variety. Fish of the cod species are numerous on the shores; so much so, that the French Government employs annually 7000 seamen to catch them, and a promontory in the southwest is, from the profit this fishing in its neighbourhood yields the natives, called the "gold-bringing region." Salmon, too, there are in plenty up the rivers, of a size and quality equal to the best, and these the natives catch and sell to dealers for, it is said, some $3 \mathrm{~d}$. per pound. A trout there is, moreover, which, report says, is equalled by no other fish in the streams or waters. These the natives partly subsist upon, and partly, and indeed mainly, barter 
away for foreign necessaries which the ships bring with them from Europe. And if we except the sulphur, which is abundant, and we may say inexhaustible, there is little Iceland can offer in exchange for the commodities of other climates which does not feed on its scanty grass-bords, or swarm on the banks of its seas and rivers. The produce which these yield, too, varies greatly from year to year; for such a region of storms and rains is it, and so invested at times, even in the summer season, along its northern shores with a broad margin of ice from the Polar Seas, that not only is the herbage often insufficient for the cattle, but there is little to reward the toil of the fisher on its streams and shores.

The interior of Iceland is for most part uninhabitable, and, though it has been surveyed by the Danish Government with a minuteness of detail without a parallel in the survey of any other country, there are immense areas in it which have never been penetrated, and only two routes, not roads, by which it is possible to traverse the island from north to south. It is in the interior a mere waste of lava, or basaltic masses, piled up, as we have said, in many quarters into mountains, some of which are above 6000 feet higll. In the south-east of the island there exists a region of 3000 square miles in extent, of an elevation exceeding 3000 feet, and covered from year's end to year's end throughout with snowenveloped glacier-like fields and mountains of ice. The prominent peaks are all volcanoes mostly gone extinct, it is thought-called jökuls; yet it is only little more than eighty vears since one of these, 
Skaptar Jökul, announced itself as still active, with a vehemence of energy equal to anything on record in the history of volcanic life. In 1783 this eruption occurred, darkening the heavens for hundreds of miles round with clouds of vapour and ashes, and causing the island to quake violently from end to end. Towards the end of May threatenings appeared in the shape of a light blue fog which rested over it; with the beginning of June the mountain began to tremble; on the 8th, it poured forth dense smokemasses, which, spreading, overhung the island like a pall; and on the 12th, after days of fire-breathing and panic, which affected the rivers and scared away the fish from the shores, it commenced pouring forth a stream of lava, which, as it sought and followed the bed of a broad lake, or river, sent the water away hissing and screaming before it into clow ts of vapour; and, after two days, lay supine, a solid lavariver of miles in length, in some places 600 feet deep and 200 broad. At the time of the eruption there burst up (from the sea-bottom, 200 miles off) an island, with three volcanoes on the breast of it, all in a state of violent action, and ejecting volumes of pumice-stone in such quantities as to block up the very seas. This island, though formally taken possession of by the Crown of Denmark, to which Iceland is now subject, disappeared in a year after, sinking slowly under the water again, and now figures on charts as a reef of rocks, whose points are from five to thirty fathoms down from the sea-level.

But the volcano on which the reputation of Iceland, as a land of fire, mainly depends, is Hecla; 
the eruptions of which, as being of late the most frequent, happen to have been most recorded. These eruptions have occurred at intervals of from five to seventy years, and frequently display an energy worthy of the earliest volcanic ages. In 1766, the eruption was such that the rocks discharged from it flew over it like bees, one of which, composed of pumice-stone, and six feet in circumference, was projected to a distance of twenty miles; the ground within a circuit of a hundred and twenty miles was covered with dust, on the average four feet deep; white paper could not be distinguished from black a hundred and forty miles away; and even the people of Orkney were surprised with showers of dust-flakes, which they called black snow.

The most remarkable of Icelandic phenomena, however, are the mud-caldrons and geysers, to which we may add the world-historical Valley of Thing-valla. Of the mud-caldrons, which occur only in the sulphur districts, by far the most worthy of notice is that of Krabla in the north; 'and it indeed is second in interest as a physical fact to the Great Geyser itself. This, it appears, is a lake, 300 feet in circumference, of boiling mud, impregnated and steaming with sulphur and sulphur gases, and abounding in jets, of which the central one starts up every five or six minutes to a height of from twelve to thirty feet, and in a column of about nine feet in diameter! In the south, these mud-sulphur pools, though not so large, are more numerous and about as noisy, emitting a stench which is intolerable, and showering a sulphur-powder all round. 


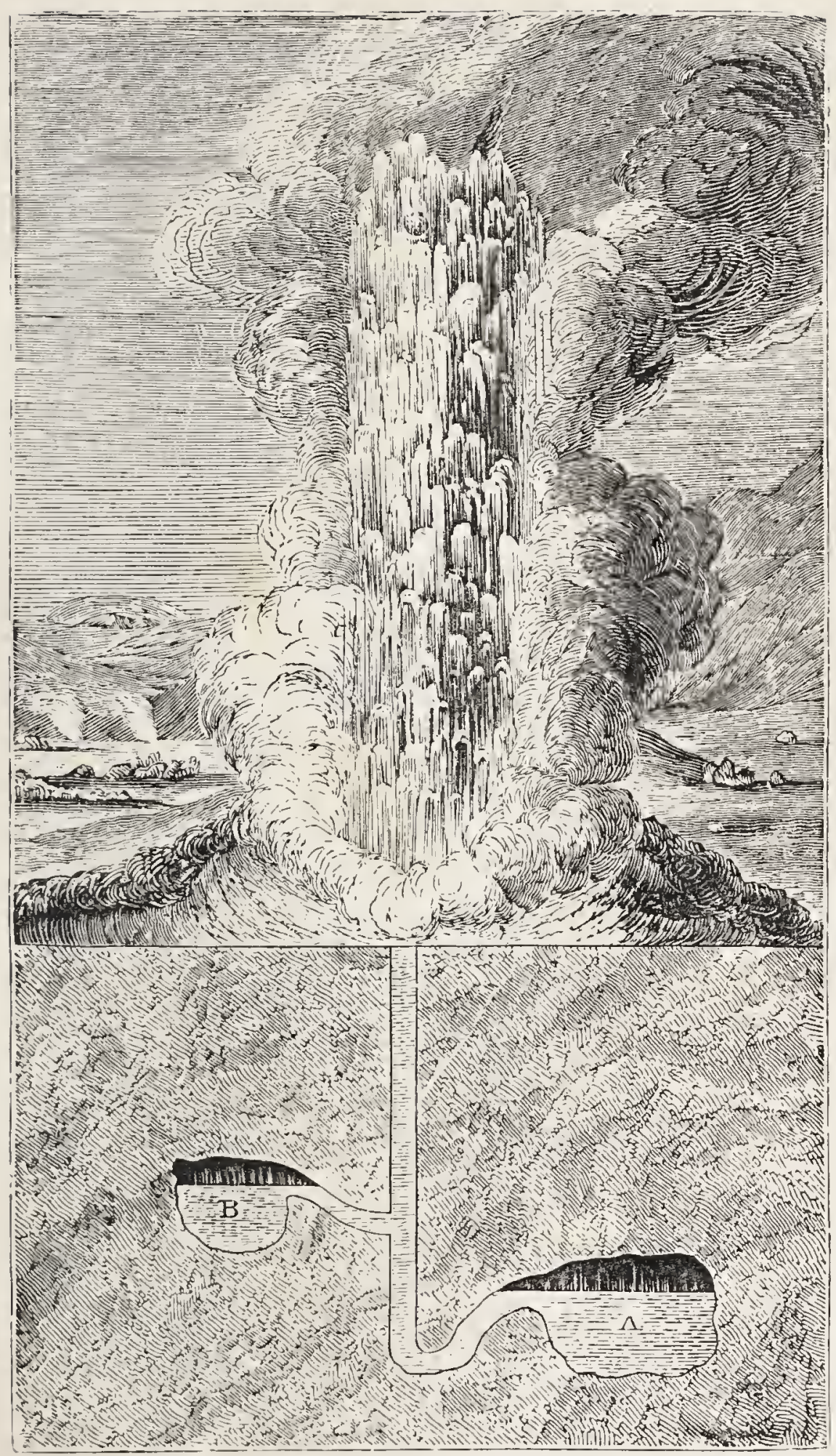

THE GREAT GEYSER.

(34ว) 

Of the more purely water eruptions, which are all at the boiling-point, the most striking are the two Geysers, i.e., gushers, or ragers, which are little more than a hundred yards apart, and issue from a surface one half mile across eacl way, which is covered with caldrons of all sizes, active and extinct. They may be seen from the summit of Hecla to the northwest, and lie some two days' ride to the north-east from Reikiavik, the capital. The smaller of the two is called the Strokr, or Churn, and shows an opening flush with the general surface round, of six feet in diameter, and which, as you look down into it, appears to grow gradually and uniformly narrower as it descends, exhibiting at a depth of twenty feet an agitation and lissing as of seething water. This geyser will sometimes continue in action for half an hour, bursting up fitfully to an elevation, at the most, of sixty feet, and discharging in all directions vast clouds of steam. By simply tumbling into it a quantity of turf, however, sufficient to choke it, it can be provoked into an eruption at any time, and it will continue discharging itself till every particle of the injected matter is cleared out of its throat. Nay, if after injection of the turf, which must in this case be administered in a gentle dose, you throw in a leg of mutton, properly protected, in forty minutes Strokr returns it to you cooked to perfection. The Great Geyser, on the other liand, which, owing to its construction, cannot be subjected to a similar treatment, presents at the surface, when idle, a circular pool filling a saucer-like basin 70 feet across and 4 feet deep, supported upon a mound 15 feet 
liigh, and from the centre of which stretches down wards to a depth of 83 feet, a shaft 8 feet wide, and uniformly so from top to bottom. The basin is incrusted all over with layers of mineral matter deposited by the water, and in appearance resembles the outside of the shell of the oyster. 'The water contained in it is always hot, and at the very edge sometimes $180^{\circ}$, since, even when there is no eruption, water at the boiling temperature is always ascending the shaft in the centre, and the surplus escaping over the sides. This geyser was, by all accounts, at one period more energetic and demonstrative in its action than it is now, going off explosively twice or thrice a-day, and springing aloft to a height of 300 feet. Now-a-days its violence is greatly moderated, but even yet its eruptions are on a scale of surprising vastness and "not only worth seeing, but worth going to see." They are now seldom, if ever, witnessed more than once in forty-eight hours, or knowr to rise above 100 feet. It grumbles a good deal before the fit comes on in right earnest; but, when it does, it heralds the act with an explosion enough in these expectant solitudes to awaken the seven slespers. The eruption lasts from twenty to thirty minutes, the waters shooting upwards jet after jet, in columns twenty-five feet in circumference, with fearful rapidity, and, as they do so, shaking the ground around with their thunderings, and darkening the air with dense masses of fleecy cloud, - of all which we must seek the cause in the still immediate nearness to the surface, in that part of the world, of its central fires. These fires engender in the bosom of 


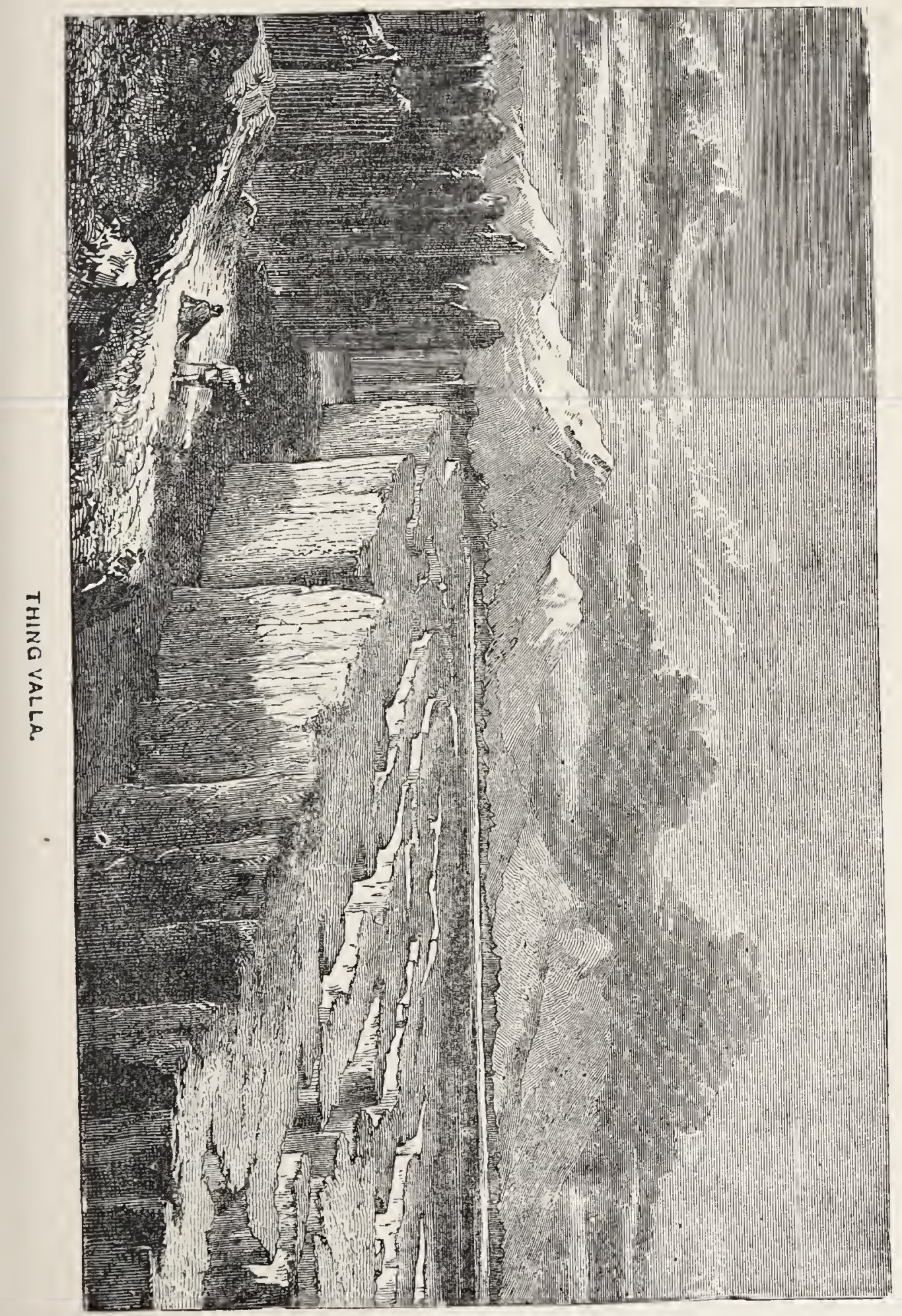



the geyser a vapour of steam, which, as it collects, must every now and then seek liberation by forcible expulsion of the water. A reference to the woodcut on p. 79 will show at a glance the structure and working of these geysers. A, B, are cavities in the subjacent rock, always more or less replenished with water. In these the water, as it boils, creates a steam, which, as it expands, both expèls the water and escapes explosively along with it.

Of all the wonders in the island not the least remarkable, in a physical point of view, and by far the most interasting, humanly speaking, is the Thing-valla Velley, lying midway between the capital and the geysers; seven miles long and from three to five wide, and in a remote antiquity formed singularly by the lava-crust composing its surface cracking at its margin and sinking to a level of 80 feet lower than the surrounding country. To the south of it, and in a line with the length of the valley, there extends a lake, the largest in Iceland, and thirty miles in circumference, with two cratertopped islands in the centre, caused by the lava which forms its bed having sunk lower still than it did in the valley, bounded all round by rugged lavacliffs, and terminated at its southern extremity by a district abounding in cones, from which are seen continually curling upwards spiracles of sulphurvapour. The valley itself is sprinkled over with a feeble vegetation, mostly of a birch brushwood, and thickly interspersed with cracks or fissures, some of which are sixty feet deep. The lava which composes its surface having not only sunk, but shrunken, 
the valley is bounded, on the east and west sides especially, all the way by more or less continuous deep rents or ravines. These are called Gjas, and are, the western one particularly, nearly 100 feet deep-the cliff formed by the lava which remains at the primitive level being in some parts 180 feet in height. But more interesting by far than the valley itself, is a small green spot within it of an irregular oval shape, 200 feet long by 50 wide, rising into a conical elevation at its northern extremity, and guarded by deep impassable volcanic chasms on all sides, except the south, where a natural causeway connects it with the surrounding valley.

Here, under the naked canopy of heaven, for 900 years annually assembled the Parliament of Iceland; for the first 300 of which they met, speaking and resolving their wisest and bravest by the help and counsel of the gods alone. Spot sacred to liberty all over the world, where men, thinking their gravest and deepest, dared to speak, act, and enforce it in the name of Heaven itself. They called their parliament Althing, that is, assembly of all, where each one who had anything to say may speak it, and make sure of an earnest response to it from all hearts-would find all prepared to draw sword for it, and shed in behalf of it their best blood. And the valley ennobled by the Althing wa; called Thing-valla, valley of speaking, where the speaker, if sincere, is listened to, and his word endorsed by all free men. In the spirit of it, a model parliament of men to the end of time! 


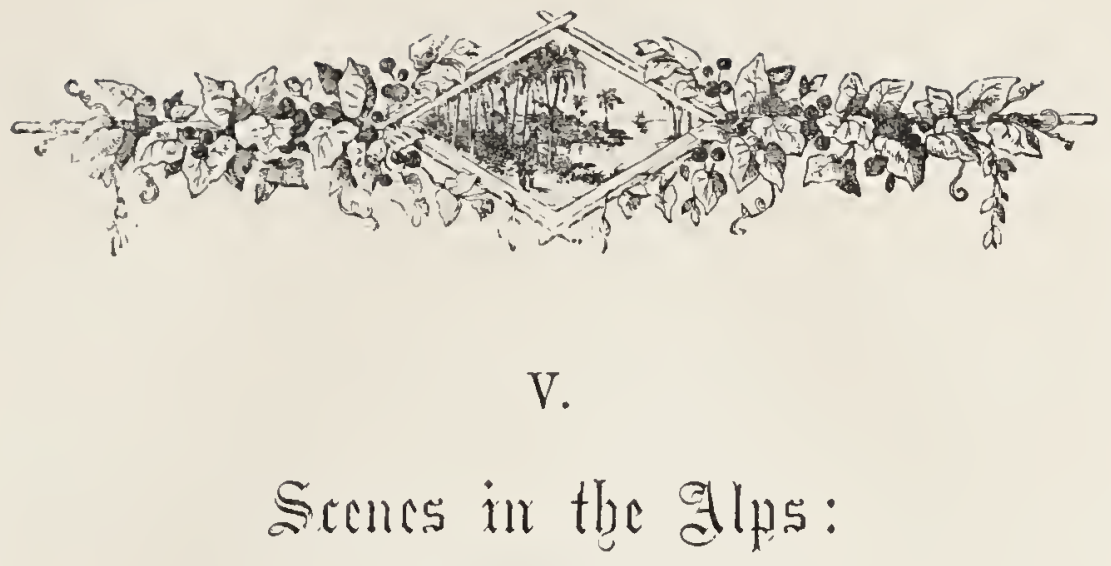

MONT BLANC.

ONT BLANC, though not the central, is
the loftiest mountain of the Alps, and
rises higher than any other in Europe, if re except Elburz, in the Caucasus, which surpasses it by nearly 3000 feet. Though little more than half the height of Gaurisankar, in the chain of the Himalaya, its elevation is more than three times greater than that of any mountain in Scotland, being 15,744 feet above the level of the sea. It is situated thirty-seven miles south of the eastern extremity of the Lake of Geneva, in the department of Haute-Savoy, France, bordering upon Switzerland on the north, and Italy on the south-east; and it extends, in a north-easterly direction, at the western termination of the Pennine chain, which stretches east. The Great St. Bernard, Monts Cervin and Rosa, which belong to the same chain, lie at intervals straight east of it; while another chain, called the western, extends straight south of it, all the way to the Gulf of Genoa, at Nice. Seen from the Valley of Chamouni, which lies prarallel with it on the west side. Mont Jlanc 
exhibits three principal peaks, capped with eternal snow; and the deep valleys which furrow this side are filled with sixteen glaciers, whose waters, as they melt, go, by means of the Arve, to swell the Rhone. The glaciers on the eastern, or Italian side, though not so fanous, are more numerous, amounting to twenty, and they send their waters, by the Dora Baltea, into the Po. Of the sixteen on the west side of the mountain, seven are visible from the Valley of Chamouni alone; which valley, though at an elevation of above 3000 feet, is a paradise for fresh purity of atmosphere, gardenlike beauty, pretty hamlets, and sublimity of scene. Viewed from it, the glacier which first strikes the eye is called Des Boissons; and this, like many others, descends far into the region of cultivation, and is fringed on both sides, along part of its course, by forests of pine, which it overtops, and with which the dazzling brightness of its white presents to the eye a startling contrast. But of these seven glaciers, and indeed of the whole, by far the most remarkable is the Mer de Glace-i.e., sea of ice-which terminates two miles above Chamouni, and which, coming down from its valley-top far up the mountains, covers an area of eighteen square miles. In order to see this glacier in its all solitary vastness, it is necessary, after crossing the Valley of Chamouni, near its top to the right, to ascend 3000 or 4000 feet higher up; and here you find yourself, on a sudden, skirting the top of a precipice on your left, from the giddy height of which, as you cast your eye down, you discern its waste expanse 
spread out below you, and overhung by frowning masses of mountain, terrible at once for their size, steepness, and sterility. The surface of the glacier, as seen from this height, resembles a sea which has been suddenly frozen, not while the storm is raging, but just when it has spent itself; and the waves, though still high, are no longer sharp-ridged at the top, but rounded. These waves run parallel to the sides of the glacier, while across their length are seen crevasses, or long, wide fissures, of a dark blue colour, contrasting strikingly with the surface, which is white. When you descend to the glacier itself, what from above seemed waves become mountains, and the trough of them valleys, with lakes and streams in them; which last, as they flow on, fall into the crevasses, run below, and issue at its lower extremity as the source of the river Aveyron. Of these glaciers, there are about four hundred in the Alps alone, some of which are twenty miles long, and, at certain points, two or three miles wide, and as much as 600 feet of perpendicular depth. They are, to speak generally, ice-rivers of extremely sluggish movement, which fill the valleys that deeply furrow the sides of Alpine mountains-i.e., mountains whose tops are always capped with snow. They are fed exclusively by avalanches, or vast snow slips, which descend at their upper extremity from above the snow line, or line above which the snow on the mountain never melts. This snow masswhich, when it descends, filling the upper section of the glacier, is of a perfectly white colour, and called névé-is composed of very minute particles, mixed 
with air; but as the surface melts under the sun's heat in summer, the water percolates the mass, expels the air from the interstices, and, by freezing round the snow particles, enlarges them into grains, which, uniting at the sides, go to form the solid icemass of which the body of the glacier below consists. This ice-mass, formed wholly from the névéwhich again, as we say, is composed of snow from above the snow line-has, from the manner of its formation, a granular texture, is gritty-surfaced, clear internally, but not transparent. It moves forward-partly in virtue of the pressure of the névé accumulating at the top, and partly in virtue of the inclination of its bed--very much like a viscous substance of the nature of tar or treacle, the rate of motion being greater at the top than the bottom, in the centre than at the margin, and greatest of all at the convex side of a winding. When the course is straight, the motion at the centre does not, even in the Mer de Glace, exceed four or five feet a-day, while at the sides it is not more than twice as many inches. A glacier is liable to crack here and there, from top to bottom, into wide fissures, called crevasses, which are sometimes parallel with its sides, and sometimes transverse; parallel if the bed happens to widen, and transverse when it increases in slopethe result in both cases being due to the strain, or what is called the force of tension, which, of course, is greatest near the top. The water formed by the melting of the ice or snow on the surface in summer pours itself, as we have seen in the Mer de Glace, down these crevasses, flows in an ever-increasing 


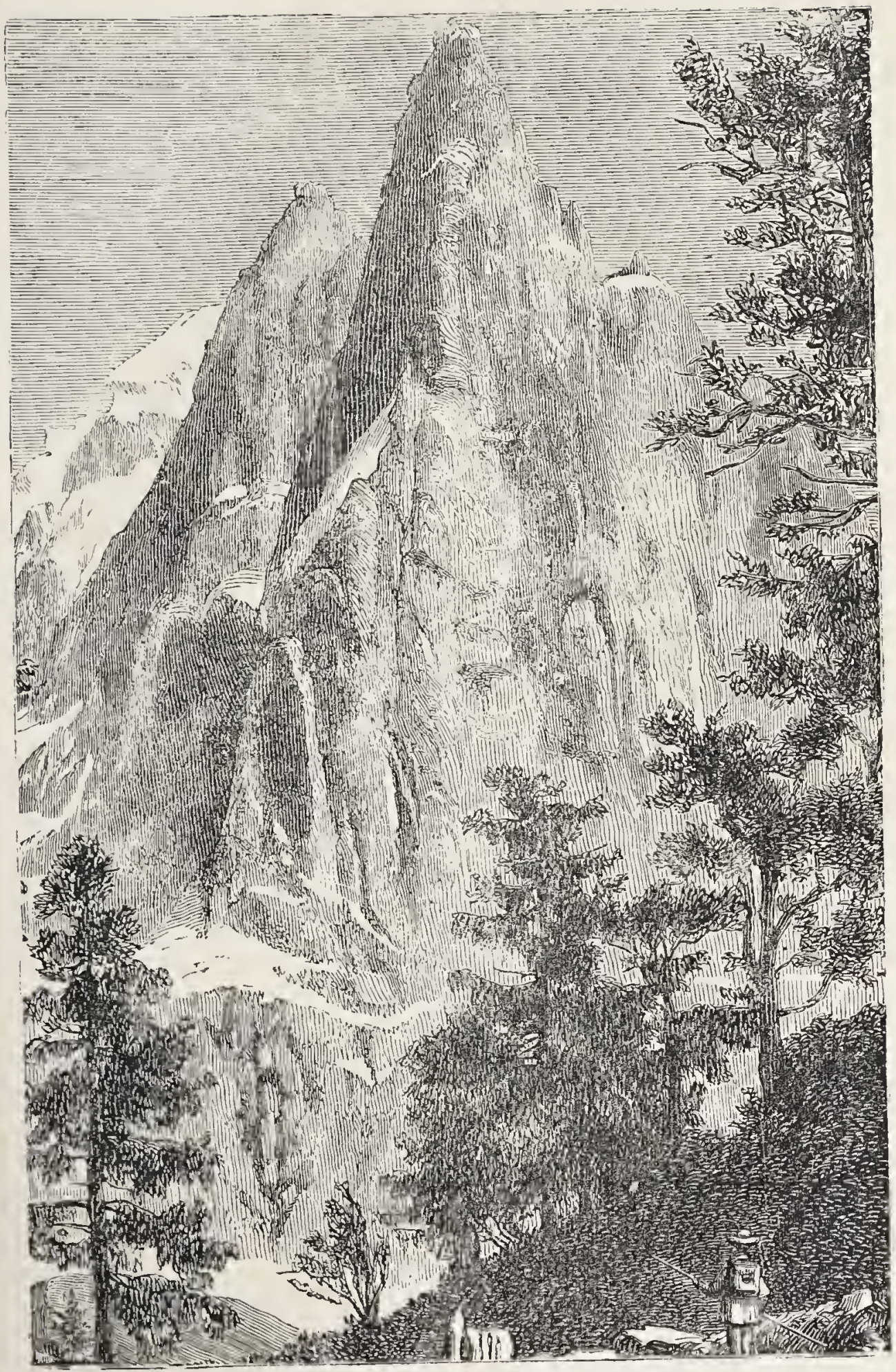

NEED'.ES OF MONT BLANC OVERLOOKING THE MER JE. GLACE. 

stream below the glacier, and issues from an arch of ice at its lower extremity, to form or feed some far wandering river. The surface of the glacier is sometimes smooth, sometimes undulating, and sometimes broken into irregular masses. It is commonly bordered throughout its extent with fragments of rock, which have descended upon it from the sides of the mountain, and are borne down with it to lie in a heap at its extremity. These masses are called moraines: lateral, when they lie along the edges; terminal, at the extremity; and medial, when, as often happens, two or more glaciers unite higher up into one. These glaciers descend frequently far into the region of cultivation, verging even on fields waving at the season with yellow corn. They sometimes dominate the pines that skirt them, as in the case of the Glacier des Boissons; and, farther up, are themselves dominated by towering, tapering peaks of rock, the more elongated of which are called Needles. Such, for instance, are the Aiguille du Dru and the Aiguille Verte, as seen in our illustrations.

The highest summit of Mont Blanc is a narrow, nearly horizontal ridge, extending alnost due east and west, 150 feet long and 48 feet wide, very steep on its north side, and sloping away at its extremities by an angle of about 30 degrees. This ridge, from its shape, is called La Bosse du Dromedaire-i.e., the Hunch of the Dromedary; and this name, in turn, gives a fair idea of its shape. Though this ridge, owing to the distance from which it could be seen, had been regarded for long previously as the summit of the Alpine region, no nne dared even to think of 
scaling it, till a Frenchman appeared, named De Saussure, who was so possessed with the idea, that he seemed sent into the world to give it birth and see it realized. For twenty-six years did this dream haunt and even trouble him, by night as well as by day; but it was not till the end of this period he saw it executed, and the honour of achieving it carried off by another-a simple Alpine peasant, named Jacques Balmat, in the year 1786. It was not until the end of the season following he himself ascended; and this, as it happened, for the last as well as the first time. His object was purely scientific; and, this attained, he cared not to repeat the experiment. He was accompanied by fourteen guides, who carried his apparatus, and assisted him in his observations. These, though finished in four hours and a half, were, owing to the rarity of the air principally, and the consequent difficulty of breathing, not executed without impediments, but they established results which attracted, and for a time engrossed, the attention of scientific people all over Europe; and these it may not be unprofitable once more to summarize and repeat.

1. The first result affected the height of the mountain; and this he estimated at about 15,000 fect. He determined this by the mercury in the barometer, which was known to fall so much for so many 100 feet of ascent; and as he found it fall from 32 inches to nearly 16 inches, he, by calculation afterwards, arrived at the elevation given. 2. While the thermometer in the shade was at 32 degrees, or the freezing point, exposing it to the sun 
-such was the rarity of the air-raised it only a degree and a half higher. 3. There was, he found, six times less humidity, or quantity of watery vapour, in the atmosphere here, than was ascertained to be in it at the time near Geneva; and this fact he connected with the intense thirst he and his party suffered on the summit. 4. Owing to the extreme rarity and transparency of the air, the azure colour of the sky was intense, to a degree seen on no lower altitude. Its depth, indeed, was such as to terrify some of the guides on the way up-it seemed, and they thought it, the dread opening into another world. The degree of intensity Saussure was able to test by the help of slips of paper, sixteen in number, of all shades of blue, from the lightest to the darkest, which, with a wise precaution, he for that very purpose carried along with him; and the result of the comparison was, that while at the bottom of the mountain the sky-blue was at the sixth shade from the darkest, it was only one remove from it at the top. Indeed, so dark is the sky vault as seen from this altitude, that it is said, with the due quantity of shade, the stars can be seen glimmering out in broad daylight. 5. It was with extreme difficulty fuel could be got to burn and watel to boil; and when the fire was kindled, it was found that the water, which at the foot of the mountain would have boiled in twelve minutes, took nearly thirty here. Indeed, no fire, or even light, would burn, unless fed by an artificial current of air, created by fanning, or blowing, or some apparatus to produce a draft. This also was an effect of the air's rarity. 6. So 
rare, or thin, was the air at this elevation, that it required two inspirations for one which sufficed at the foot of the mountain, and the breathing was accordingly twice as rapid. The necessity for this double rate resulted from the fact, that a given space-a gallon, for instance-contained at this level only half the quantity of air demanded by the system, and provided within the limits in which nature ordained us to live. 7 . The rate of the pulse, too, like the breathing, was nearly doubled, and the action of the heart, like that of the lungs, was at double quick time. In one of the party, its beats rose from 60 per minute to 112; in another, from 72 to 100 ; and in a third, from 49 to 98 . Hence fever, as well as thirst, resulted. 8. All sounds were extremely feeble; and this was due to the absence of all echo, as well as the thinness of the air. The report of a pistol which was fired, for example, did not exceed that of an insignificant cracker. 9. No one experienced any appetite for food or stimulant, only water; but for this the craving was both incessant and keen. 10. No animal, vegetable, or rock even, was visible for several hundred feet below the summit, only two solitary butterflies; and these fluttered about with a distractedness of movement which argued too painfully they had wandered out of their element, and were not at home. It is all snow or ice for 400 feet from the summit, not a spot of earth or scrap of lichen to be met with.- Such are some of the results of Saussure's observations; and they are not an unworthy reward of the zeal he showed in the prosecution of the enterprise, and of 
the labour and difficulty he experienced in carrying it out. This ascent was effected on the $2 \mathrm{~d}$ of August 1787, the greater part of it laving been accomplished the day before; and the inconvenience experienced in the course of it was due almost exclusively to the rarity of the air.

It was in the year 1760 that De Saussure-a native of Geneva, and then a young man of twentyconceived the idea he afterwards accomplished; but though he offered a reward to any mountaineer who would find out the route, or even explore it, it was not till 1775-fifteen years later-that anything like an attempt was made. It was by four natives of the valley it was first undertaken; but the rarefaction of the air and the blinding whiteness of the snow was such as to compel them, before achieving anything, to give it up. Eight years after this it was before the attempt was repeated; and it, too, was abandoned, because one of the party became ominously infected with an irresistible inclination to sleep. "The next time I renew the enterprise," said one of them, when he returned, "I shall, with a parasol and eau de Cologne, be provided against all contingencies." In 1785 Saussure himself made his first effort; but he, too, though he ascended upwards of 11,000 feet, was, from the lateness of the season, arrested and turned back by the snow. On the 6th of July 1786, six men from Chamouni inet by appointment on the Dome du Goûter; and a seventh along with them-Jacques Balmat-who they were all unwilling should join them, and share in the surely expected honour and reward. All of 
them, however, went on for a time together, and only returned to the valley when they found that the ridge between the dome they met on and the summit they arrived at, besides becoming steeper and steeper, so narrowed itself that they must go astride of it to ascend it, while the precipice to right and left was several thousand feet of nearly perpendicular depth. Only Jacques Balmat insisted on prosecuting the dangerous feat; but, when he, too, having satisfied himself of its impracticability, abandoned it, and returning along the ridge, still astride, and with back foremost, found that his companions had not only relinquished the attempt, but left without him,-being stung by the affront, he at once determined not to follow them, but to spend the night alone upon the mountain, and next day eitler discover the true route to the summit or perish in the attempt. He descended a little way accordingly, squatted under a rock which projected only partly over him, and here passed the night without wrapper of any kind, though the temperature was below freezing. Next day, therefore, with the dawn, he started on his explorations, and finished them before mid-day, redescending with the programme of the route carefully, conclusively, and, once for all, sketched and mapped out in his head,- -only the severity of the cold, and weakness from want of food, compelling him to retire, after merely scanning the way, without traversing it. On his return, he slept without interruption for forty-eight hours. When he awoke, he found he was nearly blind; and at length he began to be afflicted with a pain in the 
eyes, of such acuteness that it was feared it would result in the loss of his sight. From this misfortune, however, he was delivered by the healing skill of a Dr. Paccard; to whom out of gratitude he revealed

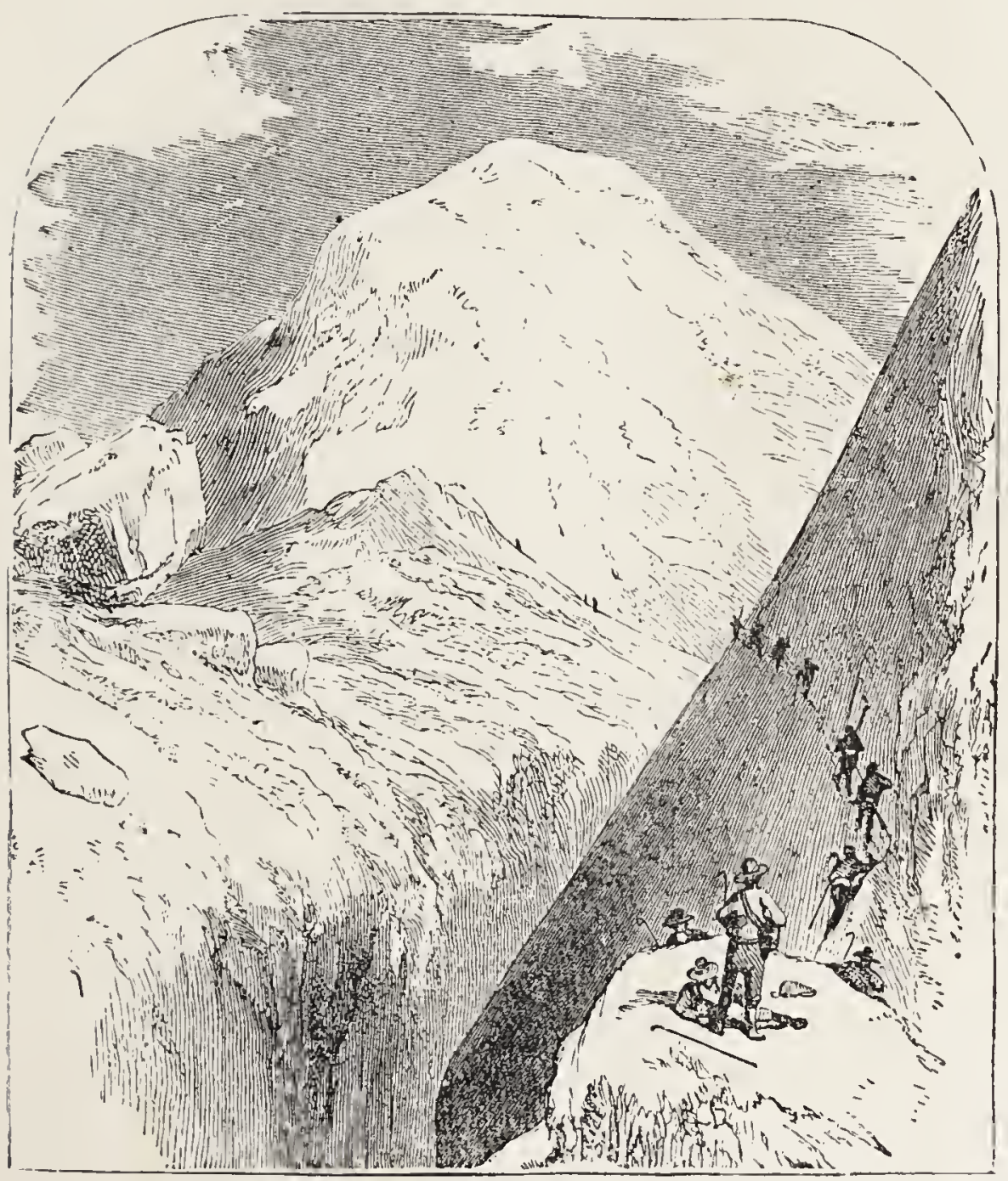

ASCENDING MONT BLANC.

his secret, and offered by way of recompense a share in the honour of accomplishing the first ascent to the summit of the mountain. This the doctor at once accepted; an? the two set out alone ou the 8th 
of August of the same year, after previously putting two of the Chamouni people in their contidence; and these were, on the following day, to summon the villagers to be on the outlook, with such telescopes as they possessed, to witness the feat. This they accomplished as they expected; and though they stayed only half an hour on the summit, all Chamouni was witness, at any rate, to the feat being done. When the two returned, Dr. Paccard was nearly blind, and J. Balmat was swollen all over the body, and especially about the lips and eyes. As soon, however, as he partially recovered-which he did in about four days-he hastened to Geneva, and unfolded his success to M. de Saussure; who next year, following in his footsteps, not only successfully accomplished the ascent, but, with science to help him, took notes, and printed them for the benefit of the world. With the exception of one undertaken in the year 1844 , his was the first and the last scientific ascent of any consequence; nor was there any great need, for the purposes of really human science, to attempt another. Those who have succeeded him-and they have been many-have done so more to experience and produce sensations, than to advance any interest worth the pains.

One other scientific expedition was attempted on the 18th of August 1820; but this, before it came to anything, proved fatal, ending in a catastrophe which is not forgotten in the Chamouni Valley to this day. The principal in this ascent was $\mathrm{Dr}$. Hamel, a Russian savant; and he, as it chanced. 
was accompanied by two Englishmen and twelve guides. After spending, as usual, the night previous to the ascent at a station well up the mountain, called the Grands Mulets, and being obliged, on account of a violent storm, to remain through a second, the most would, with the second morning, which was still threatening, have at once returned to the valley, had not the doctor proved resolute, and, sending for more provisions, given orders they should remain till the weather cleared. At eight o'clock, accordingly, when the weather at length brightened, the doctor instantly required the company to strike their encampment and proceed. The guides, knowing the dangers, at first rebelled, and peremptorily refused. One of these, however-and he of the unfortunates who perished-taking the doctor's orders for the decree of fate, burst into tears, threw his arms round a companion, and exclaimed, "I am a lost man!" One of the Englishmen took the side of the guides; but when, upon his remonstrating, the doctor stamped his foot, and, looking him in the face, called him "coward," he, without saying a word, turned round, got himself ready, and stepped onwards with the rest of the party in the rear: Everything went on without accident, or even slip, during the best of weather, till they reached the plateau, at the base of the cap of the mountain. "Never," as Hamel himself writes, "did ascent to this point succeed better, the guides themselves being witnesses; never with more speed and fewer difficulties. The snow which had latterly fallen bad the very depth and consistency best suited 
for walking over it. All were in the highest of spirits, and full of hope, despite the rarity of the air, already considerable, and which was such that my pulse made 128 beats per minute, and the thirst I felt was both keen and constant. Our guides called for breakfast before proceeding further; for, said they, 'higher up one's appetite is gone.' Here, accordingly, a cloth was spread out upon the snow, which served at once for chair and table. Each seated himself, and ate with relish to his heart's content. I got all ready for the observations I intended to make on the summit. I even wrote two notes, announcing our arrival at the top, leaving only a blank for the hour. These I intended to attach to a pigeon I carried with me, and which I meant to let off there, to see how he would fly in so rare an atmosphere, and whether he would find his mate at Sallanches. I carried a bottle of wine also, to be drunk to the memory of Saussure. At nine o'clock precisely we resumed our ascent, with the summit in our eye, and seeming close above us. 'Would you be tempted to descend for $£ 1000$ ?' said the one Englishman to the other. 'Not,' answered he, 'for any bribe you could offer.' Such was the entliusiasm of the moment in all hearts l"

Thus aniniated, the company proceeded, and commenced ascending the last slope which leads to the summit, and is called the Cap of Mont Blanc, but at the foot of which yawned an immense crevasse, 150 feet deep. They ascended this slope obliquely, in single file, according to an order agreed upon, and were all in route, each following steadily in the 
track of the other over the snow, every foot sure, and every heart hopeful and light; but as they advanced, it happened that the track they mads cut off from the snow above it the snow below, which, having recently fallen, still lay loose upon the surface immediately under it, and, being unattached, therefore instantly gave way, sliding down, and carrying, as with the force of an avalanche, every soul along with it. Three of the guides were precipitated into the crevasse at the bottom; two others, being projected with greater force, cleared it, and were pitched into a smaller one beyond, one of them up to the neck in a gulf of snow; while the rest, including Dr. Hamel and his two companions, were, strange to say, of a sudden arrested and caught suspended, on the very edge of the abyss; - the whole having descended rolling and tumbling helplessly down 300 feet of slope. The two who had cleared the crevasse lay for a while unconscious; but recovering at length, soon the one extricated the other, and both stood, for a time, silently regarding each other with a look which seemed to say, "And are we two, then, the only survivors?" In a little, however, the rest, who had, being intercepted, stopped short on the brink, having, by means of hatchets, with which they cut a footing in the ice, and mutual help, succeeded in extricating themselves from their perilous position, appeared calling to them from a height beyond. The whole assembled, and it was soon found that there were three missing; and their names were P. Carrier, P. Balmat, and A. Teiraz. Dr. Hamel was pained and sorrow-stricken to the 
very heart; while, as for the two Englishmen, they cast themselves upon the snow like men distracted, and rowed they would not quit the spot till they found their innocent companions, dead or alive. They accordingly, with the doctor and the rest, descended to the lower margin of the crevasse, and even entered it; but though they called and sounded, with the utmost personal risk, in all directions, no answer was given, and no trace of any one was found. The search was therefore given up, and all returned to the valley, each with his gloomy version of the disaster, and all persuaded that their unfortunate fellow-adventurers lay at the bottom of the crevasse, buried under above 100 feet of snow. The two Englishmen contributed liberally to succour the poor families of the deceased; but nothing could comfort the mother of Balmat. The poor old woman, after weeping lier eyes nearly blind, sank to bed brokenhearted, and in three short days thereafter expired. Sucl price, and far greater, from the beginning of the world, and all over it, is there tragically to pay, till the human kindred learn what are the possibilities and impossibilities of life.

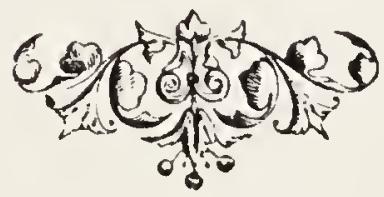




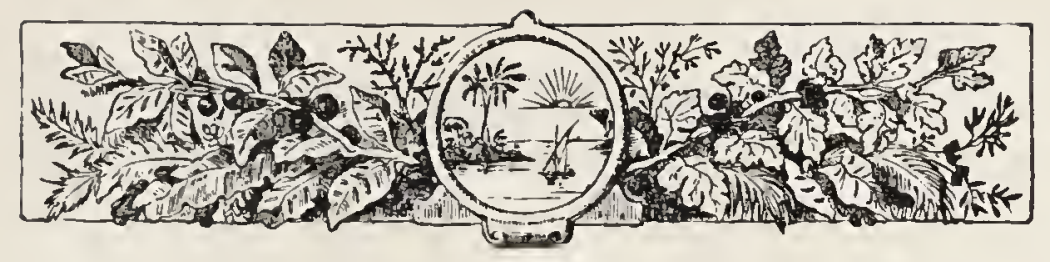

\section{VI.}

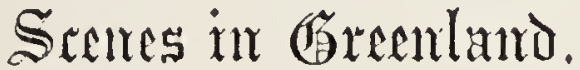

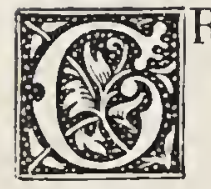

REENLAND is now admitted on all hands to be an island, entitled, however, like Australia, from its size to rank as a continent, being 1200 miles from north to south, or twice the length of Great Britain. The interior is understood to be occupied by an enormous expanse of mere ice, which, as fed by descents of snow from the mountains and the atmosphere, slopes and moves slowly northward, and sends off, now to the right, now to the left, along ravines formed by them and terminating in fiords, branches themselves stupendous, that for most part overhang and even invade the sea. One of these, called by Dr. Kane the Humboldt Glacier, and approaching by its northern flank within $10^{\circ}$ of the pole, advances from the central ice-mass upon the sea westward, and terminates in a cliff-like front 60 miles long, 300 feet high, and of unknown depth; whence, pressed forward by the mass behind, piles of ice of all sizes detach themselves. which, buoyed up by the water, float away 
as icebergs, covering the seas. This glacier is by its discoverer set down as the northern boundary of Greenland, and may be regarded as the central one itself, trending west. Beyond it land re-appears, which a party of Dr. Kane's men explored to within 520 miles of the North Pole, and to which Dr.

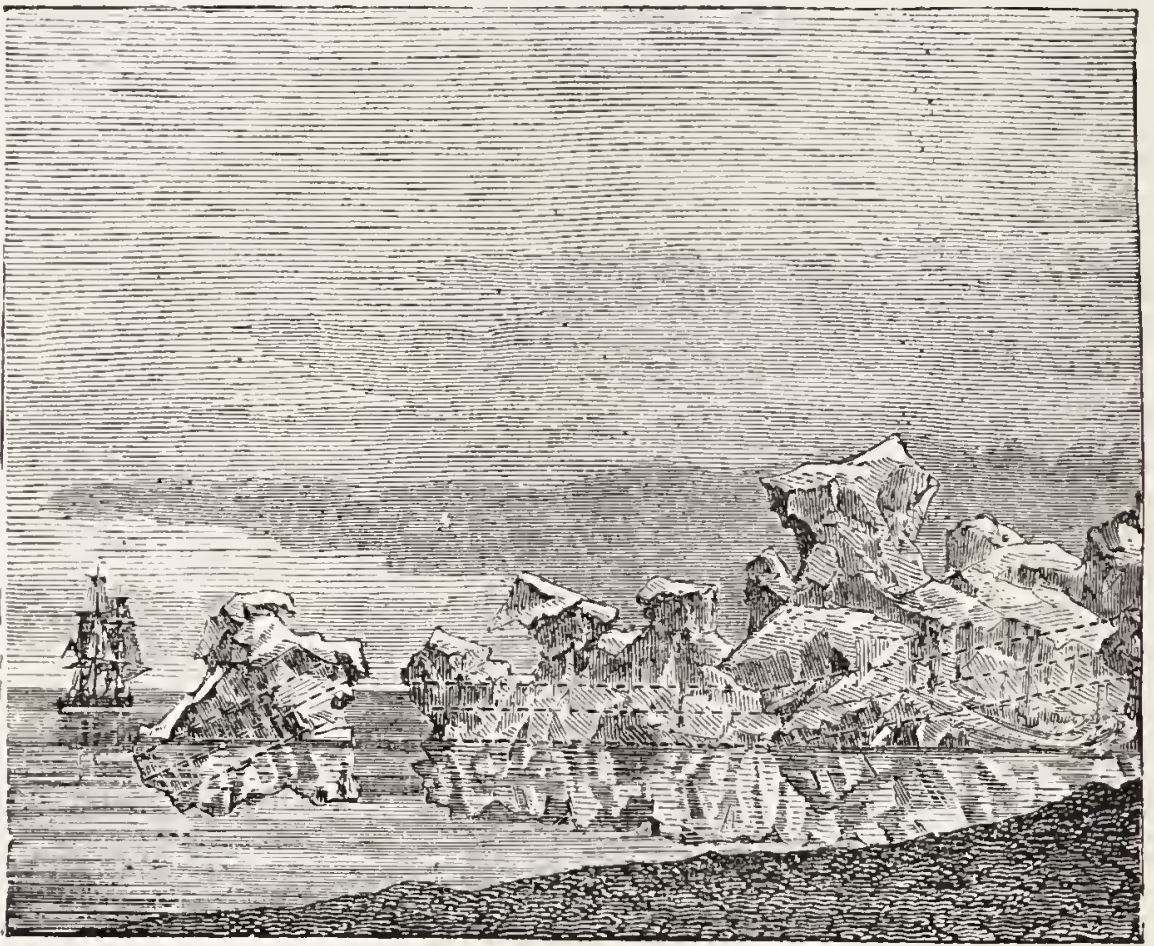

J CEBERGS FOKMING.

Kane gave the name of Washington. The south-west corner of this land rises into a rocky promontory named Cape Forbes, and the north-west into another called Cape Constitution, where the land, rising into cliffs 2000 feet high, appears to trend away east, and whence, looking athwart the channel on the left, the eye can see the opposite or strictly American 
shore stretching, or rather undulating away straight northward for fifty miles, till it is lost in the distance. The channel between was found by Dr. Kane's men, to their infinite surprise, when they visited it on the $23 \mathrm{rd}$ of June, to open gradually into an iceless sea; which, from the data they supplied him, Dr.

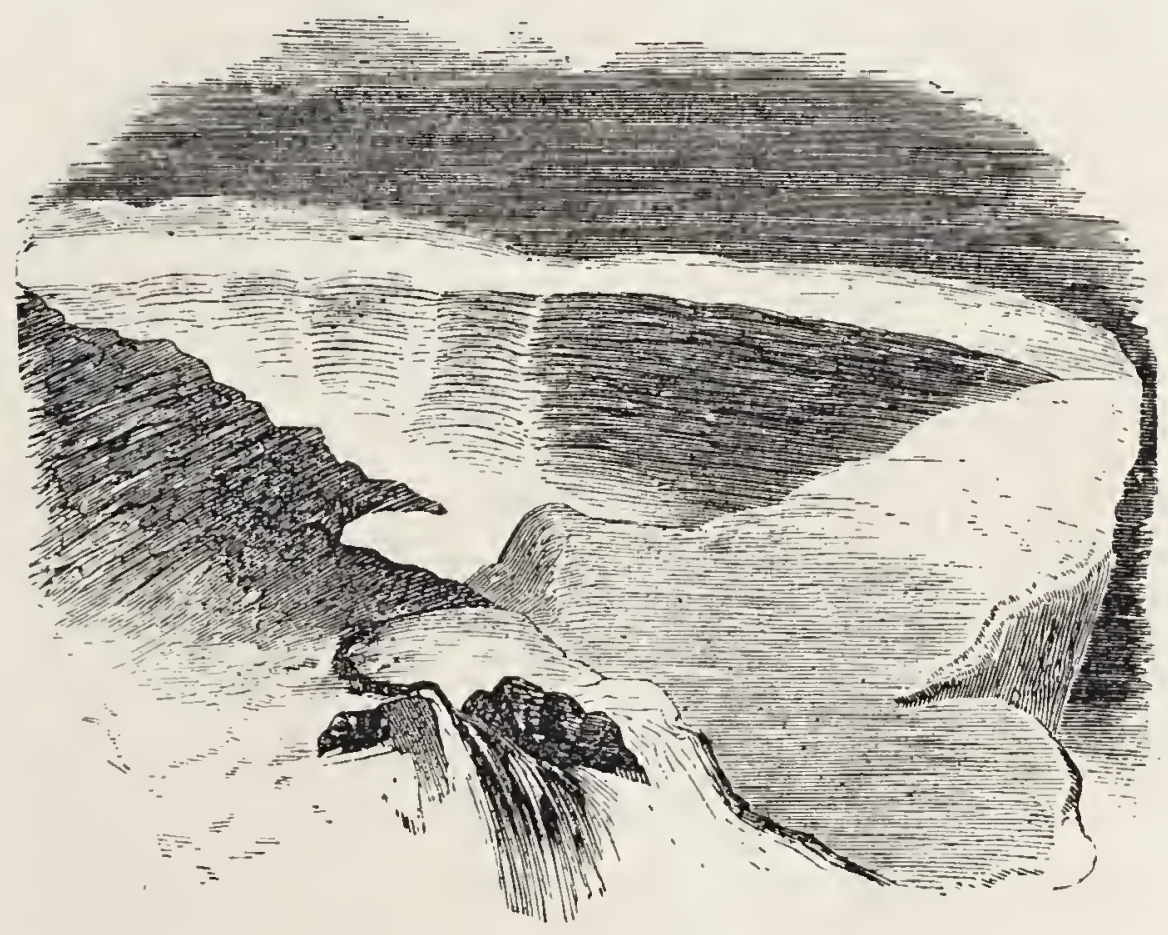

CAPE FORBE.S.

Rane calculated to cover an area of 4000 square miles, and which he faintly conjectured to be due to a deflection thitherward of the Gulf Stream.

Only the coasts of Greenland are inhabited, and even these sparsely, and, except by Esquimaux, not higher than latitude $73^{\circ}$. The settlements are principally of Danes, for trading purposes; but on the west 
coast there exist three founded for other purposes, by the Moravian missionaries. 'The Danish colonies or factories number only thirteen-the Danes themselves a few hundreds; and the trade they ply is carried on with the natives by barter, without the medium of money-skins, furs, oil, cod, \&c., being received in exchange for wheat, brandy, coffee, sugar, tobacco, utensils, \&c. Everything the natives have to dispose of can be got by barter. Dr. Kane hired a young Esquimaux for hunter by leaving with his mother two or three barrels of bread and a few pounds of pork. Reindeer-hunting is a favourite occupation in summer; and the skins are sold and sent to Denmark, where they are much prized for their lightness and warmth. These are also used by the natives themselves, as well as sealskins-which last are in especial demand for pantaloons and waterproof over-alls. Fishing is the chiet employment, yields the staple commodity, and is directly and indirectly the life of the people.

The Danish part of the population are a homely, simple-hearted, pious class, who are quite ready to give and receive friendly tokens with strangers. The Moravians, though also hospitable and kindly, are more demure, and of an old-fashioned cut, as of people who had long since seen better days. The Esquimaux are a faithful race, if you can make friends of them; but toward strangers they are invariably distrustful, false, and dishonest. Their broad shoulders give them the appearance, when seated, of 
being tall men; but their extremities are short, and so, when erect, they rather come under than exceed the average height. They are of squat figure and feature, and spend their time in hunting and sealcatching, except when they eat and sleep, which they do inordinately. Their chief diet is animal food, which they prefer in the raw state, and the blood is an especial delicacy. They move about in small communities, are of extremely filtly habits, and house themselves for the winter in huts, or snow-houses, amidst a stifling accumulation of oil and offal, quite intolerable. These are the natives of Greenland, and they belong to a nation which, though the most sparsely, is the most widely scattered of any on the face of the globe.

Greenland has been explored much further north on the west than on the east coast, owing partly to attempts, now at length deservedly given up, to find a passage westward round the north of America, and to the efforts made to recover the party of Sir John Franklin, lost in the last of these attempts. Explorations in this direction have always been attended with great difficulty; for the ice is late in breaking up, and the sea, when open, is infested with fogs and icebergs, together with currents and storms altogether baffling to navigation. The seas, too, are narrow, north of Baffin's Bay especially, and the shores bold and rock-bound; only the ships are never in danger of being wrecked upon the rocks, as the ice never melts entirely away from their bases. 
The ice which attaches to the bases of these rocks, and is called the ice-belt, becomes gradually covered with piles of rubbish and masses of stone or slate, rounded and angular, which have fallen from the cliffs above; and this breaking up, under the action of the watertorrents and thaws of summer, divides into ice-rafts, often of large dimensions, which then float away to your peril, each with its more or less ponderous cargo, down the straits into the open sea. Besides, to make explorations of any extent, one season signifies nothing, and so the ship must be provided with men and means able to hold out through an Arctic winter. A winter spent in these regions is something truly frightful even to a native, still more to one who is not; though there have been Americans as well as Europeans who have stood out two in succession, and come south again alive. In North Greenland, for one hundred and forty days in this season there is no sun, for ninety or more no twilight; the temperature is on the average $60^{\circ}$ or $70^{\circ}$ below the freezing point, often as much as $90^{\circ}$ or $100^{\circ}$, and by no device can the frost be excluded from hut or cabin. The dogs you carry for the sledging, which is essential for exploration, must be provided for, and probably three-fourths of them die on your hands, of lethargy, delirium, and lock-jaw. The men, too, cannot be prevented from taking scurvy, and becoming swollen and haggard. A month, or even a week, will work greater changes upon their appearance than a year will at home; and 
when the season returns and excursions are attempted, there is the danger of being frost-bitten, as well as of stupor and snow-blindness. The snow, if eaten, burns like caustic, inflames the mouth and throat, and causes speechlessness. Your men, too, are apt to mutiny, your ship to be ice-bound, and if your dogs die, as is most likely, you have no alternative but to face death, or risk the hazardous enterprise of escaping southward in an open boat. This was Dr. Kane's alternative in 1855; he had sailed north with eighteen of a crew in the brig Advance in 1853, spent two winters in lat. $78^{\circ} 30^{\prime}$, and after penetrating as far as lat. $81^{\circ} 20^{\prime}$, and losing two of his men, had to abandon his brig and commit himself and the remainder of his crew to boats.

The coasts in this latitude he found to be high, broken at intervals into fiords and by the channels of glacier-fed rivers, and composed chiefly of red sandstone rock; which contrasts, says Dr. Kane, most pleasingly with the whiteness of the expanse of snow, associating the cold tints of the dreary Arctic landscape with the warm colouring of more southern lands. This rock rises often from mounds of rubbish and ledges of ice into continuous cliffs of in many cases 1000 or 1200 feet of perpendicular. height; and the action of air and water upon their stratified surfaces gives them often the appearance of piles reared by the mason-craft of man. The most picturesque of these cliffs Dr. Kane found about lat. $79^{\circ}$, near Dallas Bay, and several miles south of the (341) 
Humboldt Glacier. Here of a sudden the rocks at the foot of a gorge surprisingly assume the form of a battlemented castle of imposing grandeur, frowning in dark shadow when Dr. Kane saw it, while the gorge whose entrance it commanded "was stream-

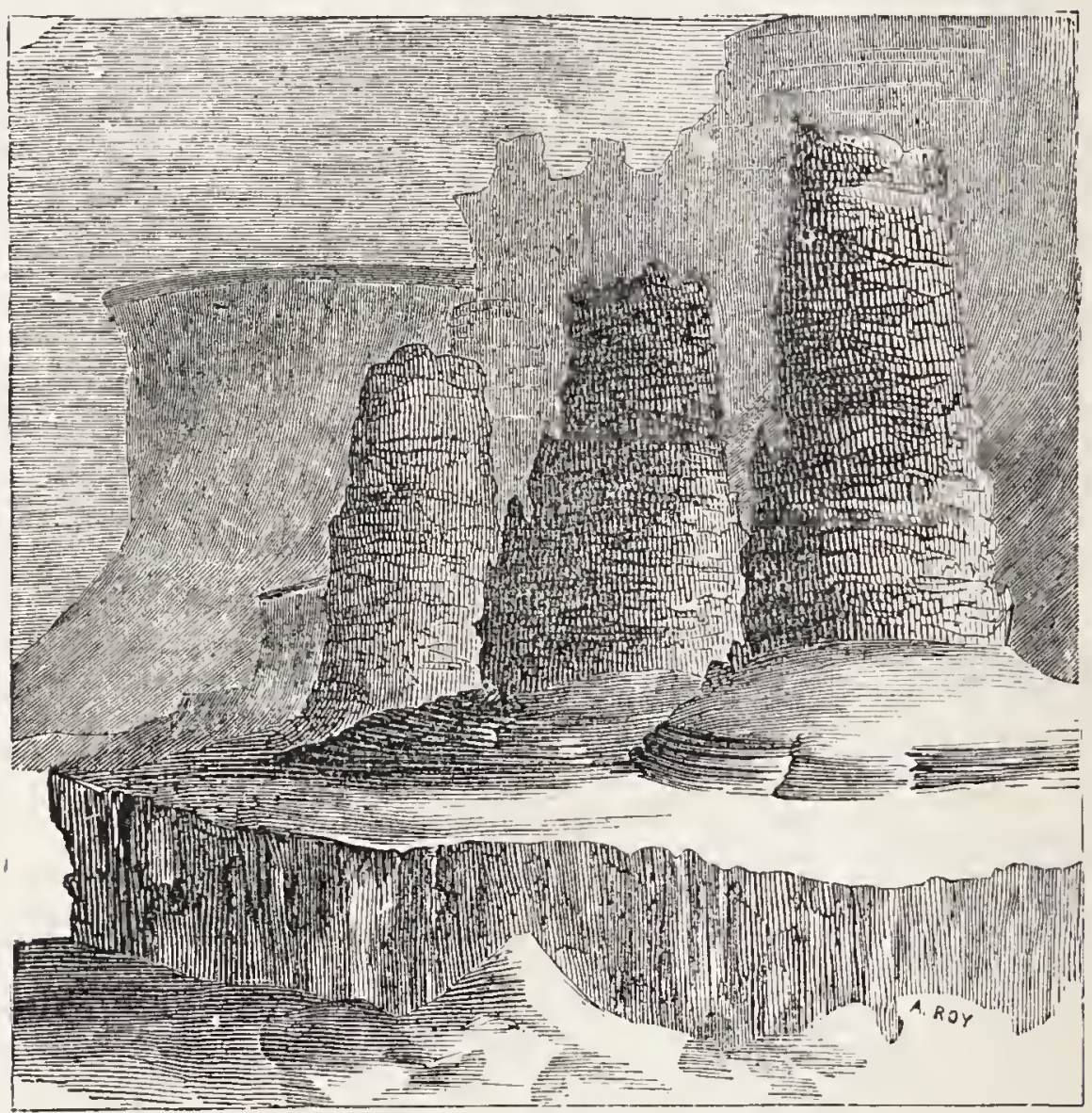

THHEE BROTHER TURPETS.

ing at noonday with the southern sun." On the flank of this "dreary semblance of a castle," and completely isolated, rise in a line three pillar-like masses of sandstone rock, to which he gave the name of "The Three Brother Turrets." A sloping mound 


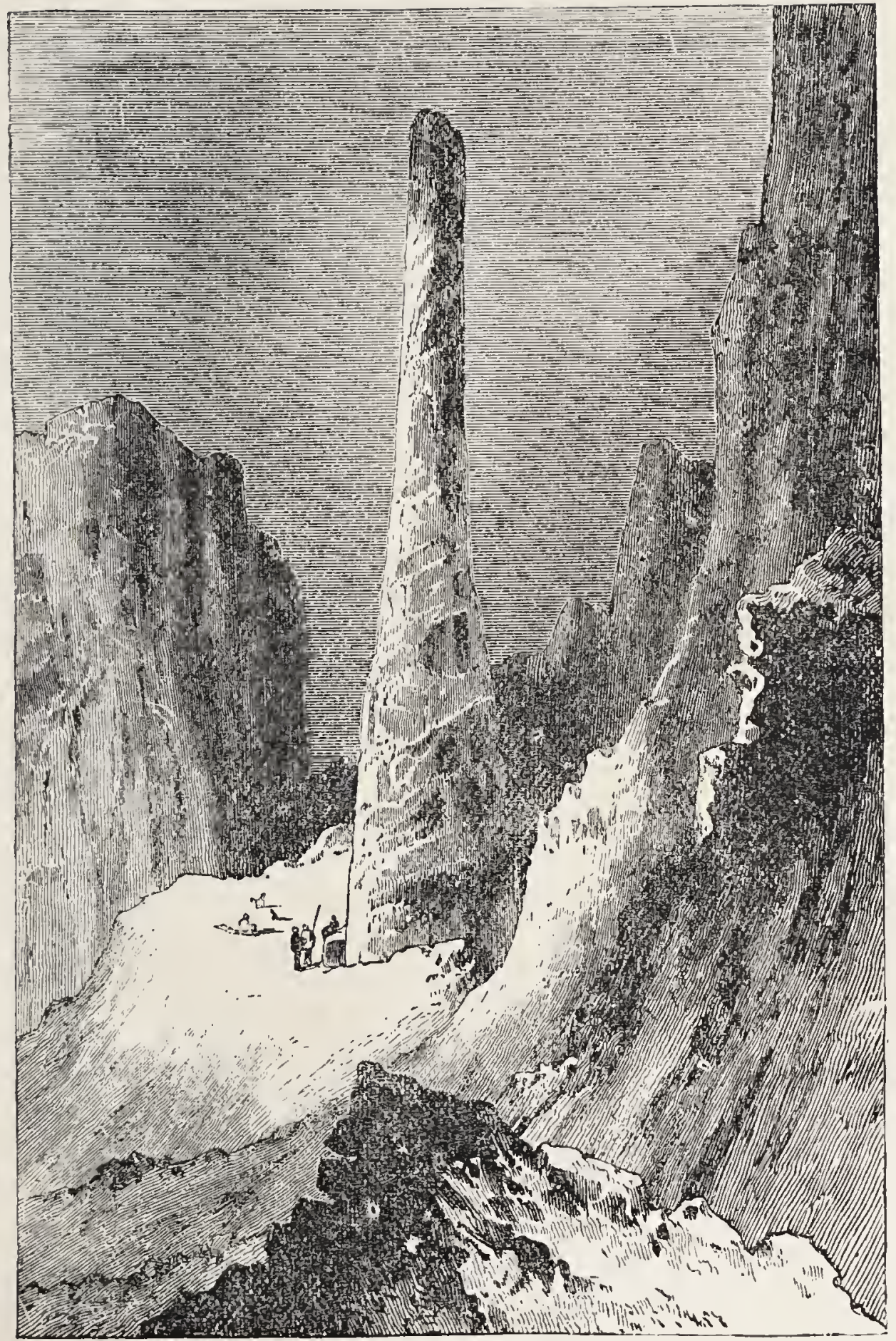

TENNYSON'S MONUMENT. 

of rubbish led to the gorge thus guarded, and as the castellated structure was at the time in shadow, the contrast between it and the surrounding whiteness made the illusion perfect. Not far from this to the northward, at the northern extremity of a long cliff of greenstone, that, " as it rears itself from a crumbled base of sandstone," resembles the "boldly chiselled rampart of an ancient city," and quite detached from it, there rises a single pillar more striking still, the shaft of which, as it overlooks a deep ravine, resembles a gigantic Trajan's Column, and is 480 feet high, while the pedestal it stands upon is 280 feet more! It seems as if designed and wrought by art of man to decorate the square and keep alive the heroic memories of some world-city; and yet Dr. Kane, when he saw it standing there in its solitary majesty, was reminded, in the then mood of his inner man, neither of high cities nor of their proud memorials, but of the surpassing grandenr of a single life melodiously led, and rendered, as it were, apart from and above them all. Such to him, communing in these solitudes, seemed the life of Tennyson; and so he not inappropriately called the pillar "Tennyson's Monument."

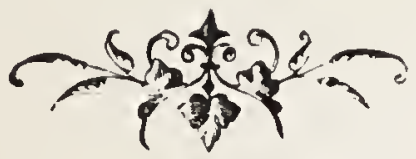




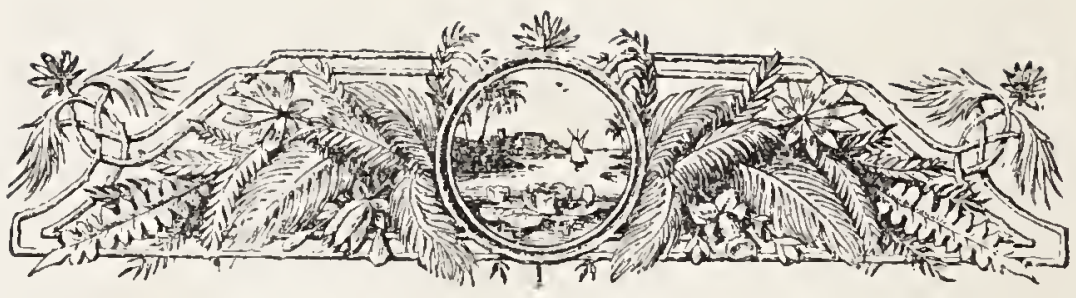

\section{VII.}

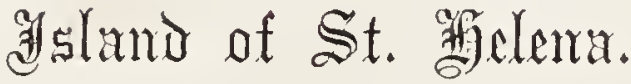

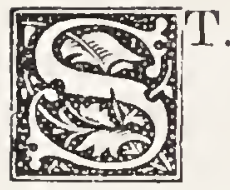

T. HELENA connects itself with the rest of the world by two main interests; - as a halting-place for English vessels on their homeward-bound voyage from the East; and as for six years the last, lonely, exiled dwelling-place of the First Napoleon. It is literally one of the far, or rather furthest-off islands of the sea, being 1200 miles from the African Continent, 2000 from America, and 4600 in a straight line southward from London. Rising abruptly out of the ocean, "like a plum-cake upon a table," it is $10 \frac{1}{2}$ miles long, 7 miles broad, and 28 miles in circumference, facing the sea in all directions with a wall of perpendicular rock from 600 to 1000 feet in height. This rock, which is throughout volcanic, and of unknown date, rises more perpendicularly on the north than on the south side of the island, and is composed of basaltic precipices of the most fantastic outline, and rent often into fissures from the top to the bottom. Of the inlets by which the island can be approached 


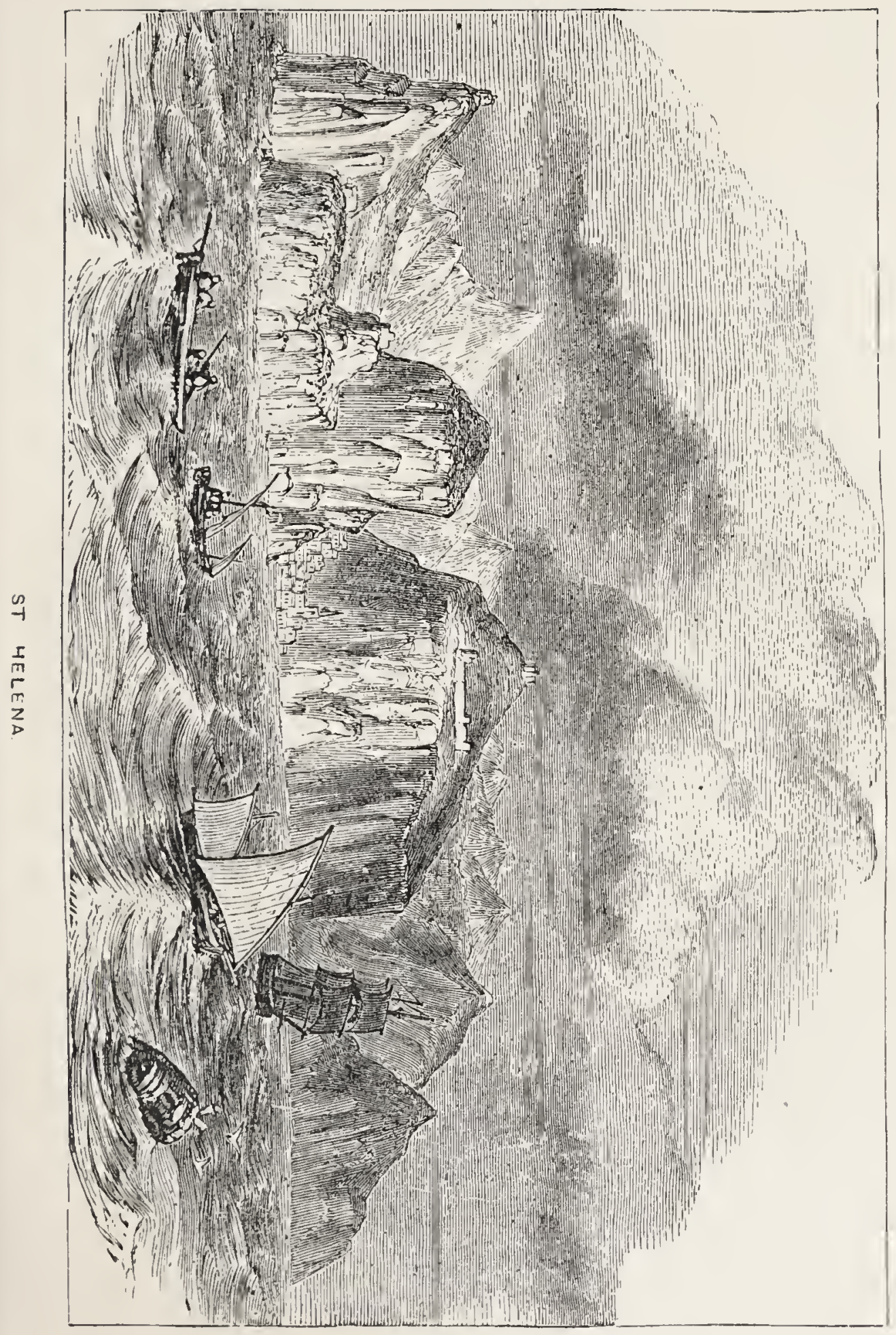



and a landing effected, there are four, three on the north-west and one on the south-east; and all these are, or were, commanded by forts sufficient to defy even a formidable invasion. No ship can approach it from Europe unless by first sailing past it far to the south and west; and in the days of Napoleon's captivity there was not a nook or cranny on which an invader could, by the faintest possibility, succeed in planting a foot-sole which was not fortified and guarded. - With the exception of two plains, of which the larger is that of Longwood, and contains $\mathbf{1 5 0 0}$ acres of fertile land, the island is entirely occupied by a ridge of hills stretching east and west, from which branch off, at right angles, a number of minor ridges, with narrow, mostly verdant valleys between. The highest point of the central chain is towards the east, and called Diana's Peak, 2700 feet; but there are other six or seven peaks along the chain, of which four or five are not 500 feet lower. These hills are in some cases naked to the summit, in others covered with shrubs and trees, especially up the sides. Water of the purest and freshest exists everywhere in rich abundance, and there are said to be no fewer than 160 springs, some of them issuing from the sides of the rocks by tiny picturesque cascades; and spots there are of surpassing beauty here and there, though a lonelier and more dreary hardly exists than that selected by Napoleon for the place of his grave-verdant, indeed, but entirely secluded, and only accessible by one winding path- 
where the eye can descry no object except the shifting aspect of the sky above!

Though within the tropics, the heat, except when reflected in still weather from the sides of the bare rock, is never excessive; and indeed of the climate generally, it is said it is never so cold as in England, and scarcely so hot. It is by no means uncongenial to a European constitution, and is in its atmosphere, no less than its supply of fresh provisions, peculiarly adapted for reviving and re-invigorating the exhausted voyager on his way home from the East. The rains, though sometimes impatiently waited for, are in the main regular and abundant, especially in February; and thunder-storms and tornadoes are but seldom witnessed, though it was amidst such Napoleon's spirit passed away. The atmosphere, too, is of such transparency that vessels can be seen at sea to a distance of 60 miles.

When discovered by the Portuguese, in 1502, it was one unbroken forest, without inhabitant. The trees appear to be now all cleared away, and others, native and imported, occupy their place. Some of these are available for their timber, and a number vield an aromatic fragrance when burned. Myrtles grow to a height of 30 feet; a species of fern, with leaves five feet long, grows to the height of 20 feet; and the hills of the interior are covered to profusion with furze, imported from England. The sea breezes here are the great enemy to vegetation; but in the sheltered valleys almost any of the tropical or 
European fruits will grow and ripen. The common blackberry, for instance, increased to such an extent after being planted, that in 1780 it had by peremptory order to be extirpated, root and branch; while so prolific is the potato, that three crops are often raised in a single year.

Cattle, principally of English breed, with sheep and poultry, are reared in great numbers, to meet the demands of vessels passing; and goats and rabbits especially swarm plentifully. Sea-fowl of various kinds breed in thousands round the cliffs; game, in the shape of pheasants, partridges, and guinea-fowl, abounds in the preserves; while among the birds of the linnet species there is one here which "builds two nests, in the upper one of which," says Martin, "the male bird sits and serenades the female in her incubation." Fish, too, throng the waters round in such shoals, and take the bait so readily, that the amateur fisher is apt to grow weary catching them.

The population numbers about 10,000, and consists of whites and blacks in nearly equal proportions, the former of whom are remarkable for the wonderful fairness and freshness of their complexions. Those born on the island are of a quick, apt faculty, and a proof in point to show that, as the Greeks be. lieved, the air has something to do with intellect.

St. James's Town, which stands squeezed into a narrow, tortuous valley, between two lofty mountains, at the head of St. James's Bay, and is the only considerable place on the island, has a pleasing, com- 
fortable aspect, with its pretty, white, tidy-looking houses, shaded and adorned with trees, generally in full leaf;-no undesirable "nan's nest," or habitation, wherein, with a little more activity and scope, the human being wants not for means and appliances. The country immediately to the rear of James's Town is, for the space of two miles, barren and disappointing; but beyond, it opens at once into a region of rich verdure and cultivation, dominated by wooded heights, and enlivened by handsome country residences and villas.

This island has a somewhat singular history of the colonization. Discovered by the Portuguese on St. Helen's day, 21st May 1502, it was not known to the rest of the world, so secret was the discovery of it kept, till Captain Cavendish came across it in the year 1588. It was first colonized by a Portuguese nobleman, who, having for a crime in India been mutilated and shipped home in disgrace, prayed the captain to land and leave him here. This the captain consented to do; and here the nobleman remained, clearing and cultivating the soil, planting the seeds of trees, and rearing the animals his commiserating friends sent him from Europe, till he was removed after four years. This settler was by-and-by succeeded by four slaves, who multiplied erelong into a population of twenty. These, however, threatened, especially if they went on increasing, to consume all the fruits and live-stock on which the ships now depended; and so they were, by orders of the Govern. 
ment, hunted down and destroyed, as if, poor fellowmortals, they had been only vermin! A friar of the Order of St. Francis, too, tradition says, was once sole tenant of this lonely island: but when we come to inquire into his fate, the ascounts are discrepant; for one says he died after a life of austerity of fourteen years' duration; and another, that he was expelled, because lie took to roguery, and killed the goats to earn a "comfortable penny" by the sale of their skins; which we cannot help thinking must be an idle, wicked slander, against the good man.

But the island is principally interesting to the rest of the world as the scene of the last days of Napoleon Buonaparte. Here, having surrendered himself into the hands of the British after the defeat of Waterloo - in 1815, he lived restricted and in exile; and here, in 1821, lie died struggling vainly witlı his fate.

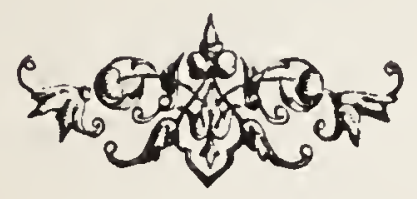




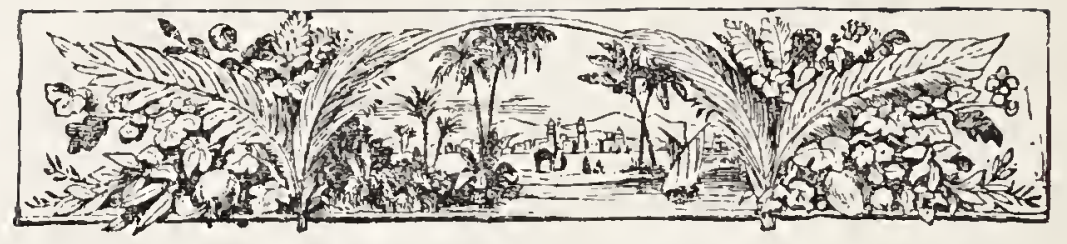

\section{VIII.}

\section{过sland of st. 零ilox.}

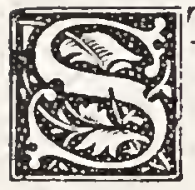

T. KILDA, or Hirta, as it was anciently called, is a small, solitary, remote island of the Hebrides, lying in the Gulf Stream, 60 miles from Harris, 140 miles from the mainland of Scotland, and 220 from the north of Ireland, in the latitude of Tain and on the meridian of Cork. It is 3 miles from east to west, 2 miles from north to south; a bold, precipitous mass of rock, ascending to a lieight of 1500 feet, and visible at a distance of 30 miles. It rises sheer out of the Atlantic by a giddy cliff-like front all round, except at one opening on the south-east and another on the west; and a landing is possible by these only in calm weather, which in this latitude is the exception, not the rule. The bay to the south-east runs inward for nearly half a mile, and only at one point on the north side, at its head, can you, with every furtherance from the natives who erowd to your assistance, bring your vessel safe to and escape ashore. About one quarter of a mile from the head 


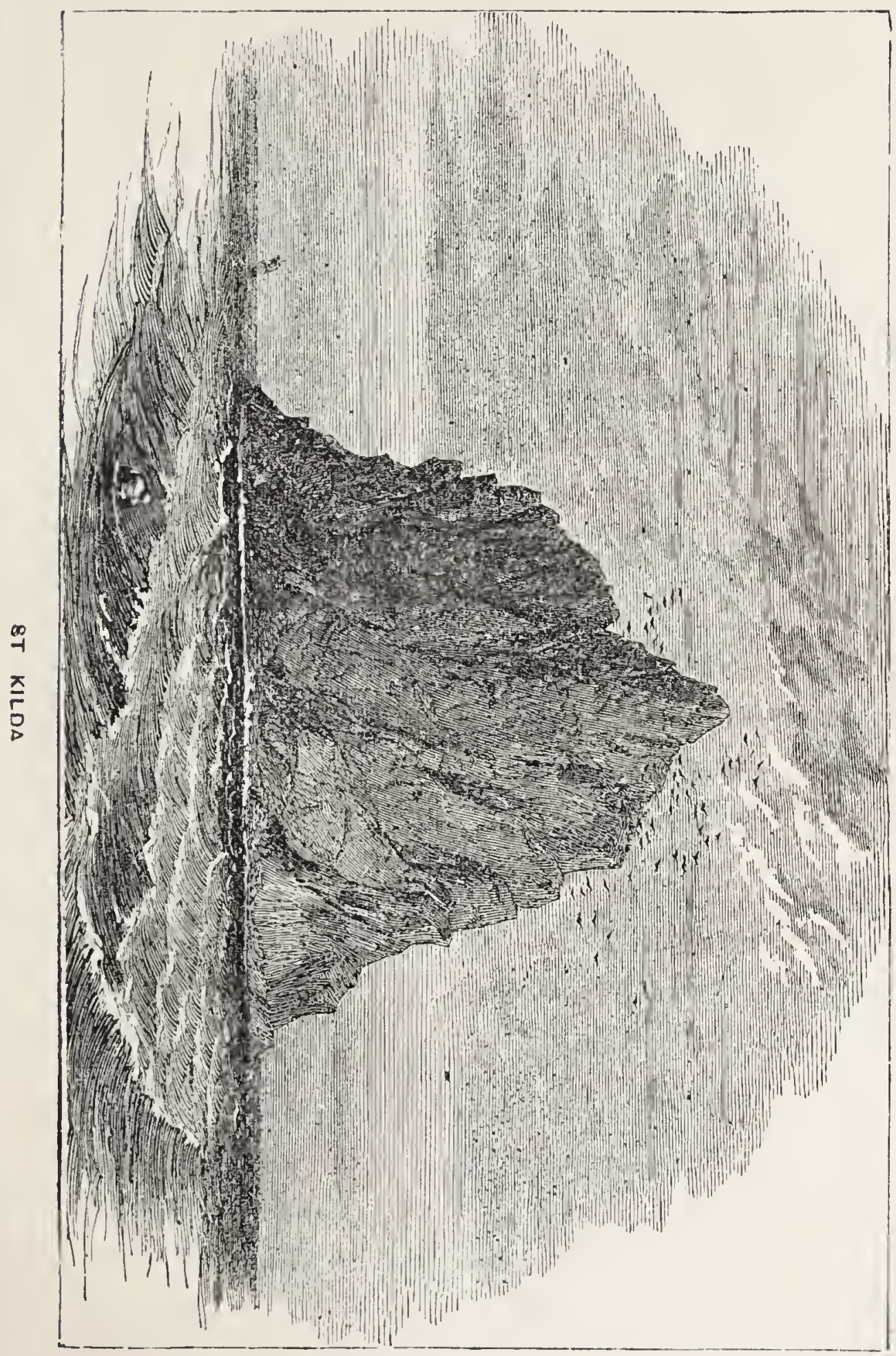



of this iron-bound bay, in a narrow glell, which is the landward extension of it, and overhung by dark precipices, are the houses of the natives, arranged in a double row of some thirty mean flat-roofed cabins of stone, cemented with turf and thatched with straw. These houses consist each of two apartments, one of which is occupied by the family and the other by the cattle in winter, the whole population at the last census amounting to only seventy-eight souls. Isolated enough from the rest of the worid and its history, there they live; but not unrelated, for all that, to the thoughts and feelings, lopes and fears, common to all of us.

The island, which rises into four eminences, one of which called Conachan, overliangs the sea on its west side in an almost perpendicular cliff 1400 feet high, the highest in Great Britain, is covered with a black loam five or six inches deep, and this with a rich green sward of fine smooth turf. The sward affords pasture for some 80 or 90 head of cattle and about 1200 sheep; while only a small portion near the village, skilfully, plentifully, and economically manured, is all the natives ever cultivate. This spot, which they reserve for tillage, yields, by favour of soil and climate, generally both an early and abundant harvest, the crops consisting chiefly of barley, oats, and potatoes, and the sole implements of husbandry being the spade and the rake, together with a mallet to pulverize the clods. So well managed was this department of industry at one time in the island, 
that the natives were able to export a little and reserve enough; and if it is otherwise now, as the tariff assures us it is, this is because the present generation consumes a greater quantity of farinaceous food than their fathers. Garden husbandry, it seems, is unknown among them. As there are neither trees nor shrubs on the island, there are no fruits; and as the hum of a bee was never heard within its borders, there is no honey. Water there is, of the clearest and purest, welling here and there at all seasons, by accessible outlets and inaccessible; and in one case so cool is it, that by immersing your hand in it for a space, your frame will begin to shiver-though no one that we have heard of has ever thought, as it is alleged the worshippers of Apollo in Greece did in a similar case, of ascribing the shivering to a divinity, and calling it inspiration. The air is sharp and wholesome, and the climate, but for the tempests, which are both frequent and furious, not so severe as might be looked for. The winds, particularly the southwest, and the rains they bring with them, are the enemies the natives most dread and especially guard against; and the sea around is in the main so violent and masterful that they seem not at all at home in it. There is no playing with the waves here as round the islands of the South Seas, where, though both wild and high, they roll landwards over a shelving shore, and you can therefore both ride them safely and dismount from them at will. Here. the waves are the arms of a huge, dumb, unheerling. 
unrelenting, hundred-handed monster, dashing the boldest and stoutest swimmer like an idle air-bubble to irremediable ruin upon the rocks. Nevertheless, the St. Kildians are not inexpert fishermen; for of the fish, which are abundant, they catch more than they consume.

There are on the island horses of a diminutive kind, and goats, besides the sheep and cattle we have mentioned. The cows and the ewes are milked, and the milk yielded is mixed and made into a cheese which is in great favour, and taken and sold at Long Island, their only market. The sheep, which have usually a profusion of horn, short tails, and spare coarse fleeces, yield a good mutton, and are available to the natives through the carcasses and wool for both food and raiment, for exportation alive as well, and barter thereby. Besides those on St. Kilda, there are others, anounting to 700 or 800 , on two of the five or six rocky islands lying scattered about, and mostly possessed by mere seafowl. Of the sheep on one of these rocks, half a mile to westward, Martin, who visited the island more than a century and a half ago, tells us, "each of them has two or three lambs at a birth, and every lamb so fruitful that it brings forth another before itself is a year old."

But the chief dependence of these istanders is upon the sea-birds which swarm here in countless numbers, and the solan goose especially. This bird is in these regions literally the prince of the power of the air, 
and monarch of every rock he surveys. Of these, it is said, they succeed in capturing 20,000 yearly, salting and consuning the carcasses, and delivering the feathers to the tax-man of Macleod of Harris, the proprietor, by way of part-rent. They take thein from their nests while young, and just before they have wing enough to fly; and this, their chief occupation, is about as hazardous and dangerous as any that falls to the lot of man. Two men set out together, provided with a tough, thirty-fathom rope of cow-hide, plaited threefold, and protected against abrasion by an envelope of similarly wrought sheep-skin; and attaching themselves, the one to the one end of it, and the other to the other, hold on, while now one, now the other, swings himself down the face of a rock overhanging the sea, in quest of nests. This rope is the most prized of all their heirlooms; and a lass whose father is able to give one away with her as her dowry, is equal in the eyes of swains of these parts to an heiress elsewhere of broad lands and proud castles.

The people, though poor, clad in home-spun, and ignorant enough of our civilization and its history, suggest not uninteresting or unedifying thoughts to our meditation. Centuries ago, they were not neglected by the Church of Rome; for here are the ruins of two if not three Roman Catholic churches. Neither have they been uncared for, of late years at any rate, by the Protestant Church, to which ever since the Reformation they have at least nominaliy 
belonged; for they liave now a missionary and schoolmaster, who, we hope, are both faithful men. Not long ago, they could neither read nor write; and now, we trust, they can do botll, and are wiser and not worse. They are primitive, simple, homely, and virtuous in their ways and thinkings; and, though not quite so cleanly as could be wished, temperate, moderately active, and modest-hearted. They have had, and still have, their trials, like the rest of us. Above a century ago they were nearly all swept away by small-pox, and now three out of every four of their children die on the eighth day. They are of the Celtic race, and show its best qualities within limits-are ardent without avarice and ambition, and affectionate without ferocity. They decide every. question of moment to all the community by vote of the majority of their elders, and they live in a commonwealth in which the prosperity of one is hailed as being what it really is, the good of all. Love of country attaches them warmly to the soil of their fathers, and few of them ever exchange it for a settlement on a foreign straud. "Happy land!" exclaims M'Culloch; "if this island is not the Utopia so long sought, where is it to be found? Where is the land which has neither arms, money, law, physic, politics, nor taxes? That land is St. Kilda . . . No tax-gatherer's bill threatens on a church door; the game-laws reach not gannets. Well may the pampered native of the Happy Hirta refuse to change his situation. His slumbers are late, his labours are light, and his 
occupation is his amusement, since his sea-fowl constitute at once his food, his luxury, his game, his wealth, and his bed of down. Government he has not, law he feels not, physic he wants not, money he sees not, and war he hears not. His state is his city, and his city his social circle; he has the liberty of his thoughts and actions, and all the world are his equals. If happiness is not a dweller in St. Kilda, where shall it be sought?"

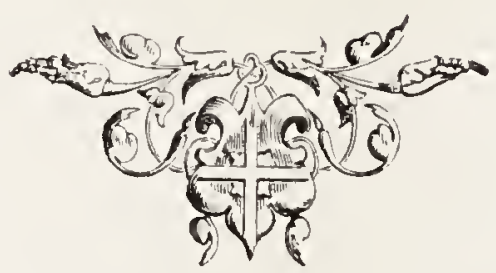




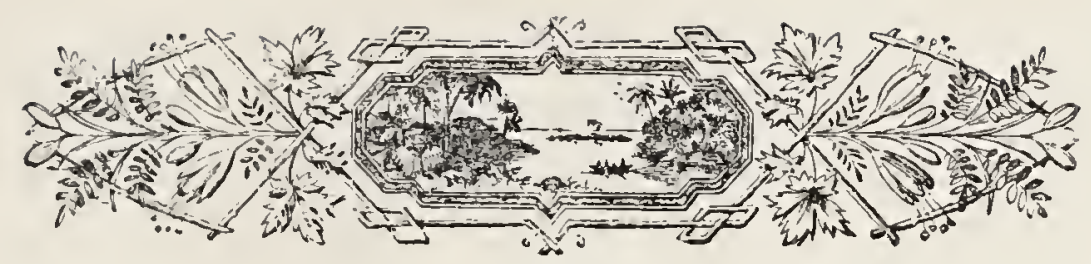

\section{IX.}

\section{Clbe firll of the staubbarly.}

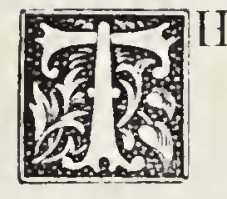

HE Staubach is universally reputed to be the highest waterfall in Europe, worth the name, descending, as it does, a perpendicular height of between eight and nine hundred feet-an altitude equal in elevation to that of Arthur Seat, near Edinburghl, above the level of the sea. It is one of thirty existing in the deep, narrow Valley of Lauterbrunnen-i.e., "Valley of no end of fountains" - which extends southward from the eastern extremity of Lake Thun in Switzerland. From Berne to Thun, the distance in a south-easterly direction is sixteen miles; from Thun along the northern margin of the lake to Unterseen, on the east, is ten miles more; and from Unterseen up the valley to the Staubbach is an incline of seven miles, or a walk of two hours and a half. The road up the valley skirts at its commencement, on the right, an old square turret-flanked ruin, called the Castle of Unspumner, and celebrated as the residence of Byron's Manfred, and about two miles from the 
lake forks into two; the branch on the left making for the Magic Peak of the Wetterhorn, seen at the crossing; and that on the right leading direct to the village of Lauterbrunnen and the falls, and offering in the distant vista gleams of the stainless Jungfrau. The forking of the road here represents a forking in the valley, of which the one on the left is traversed by a stream called the Black Lütchine, and that on the right by another, which goes to join it, called the White. The Valley of Lauterbrunnen, on the right, is steep as well as narrow, and closed in on botl sides by nearly perpendicular limestone precipices, resembling walls, from the brows of which the streamlets we have mentioned are seen liere and there floating downwards, like hanging, waving bands, woven as it were of silver. These cliffs are often of great height, and exhibit in one instance very singular contortions in the limestone strata.

The village itself, seen on the left of our view of the fall, and nearly half a mile distant, is a confusion of mostly rude dwellings on both sides of the stream, which the Staubbach contributes to augment. It contains about 1500 inhabitants, and is nearly 2500 feet above the sea; - a cold region on the whole, with a climate unfavourable to the finer cereals and orchard fruits, and so closely pressed upon by shading precipices as to have no sun in summer before seven o'clock, or in winter before noon. The Staubbach, which is the largest and most remarkable, as well as loftiest of the streams, that, at one time in in- 
creased, at another in diminished numbers, find their way as silvery cascades orer the cliffs, is not to eye or ear an imposing spectacle, so far at any rate as to impress the beholder with a sense of vastness or force. The body of water is at the best by no means enormous; and soon the whole is in its descent dashed noiselessly, by the mere resistance of the opposing air, into spray, and erelong into a fine mistlike rain. It is this powdery appearance it has at all times that at first suggested its name; for Staubbach means literally "dust-burn" or torrent which descends in dust. The impression it makes varies with its own mood and that of the spectator. Byron likens it, in its wavy curvings, to the tail of a white horse streaming in the wind. "It is neither rnist nor water," he says, "but a something between both; its immense height gives it a wave or curvea spreading here, or condensation there-wonderful and indescribable." A waterfall one-third the height, north-east of Moffat, in Dumfries-shire, suggests a similar comparison to the Scottish peasant; but he, with a humour which beseems the countryman of Robert Burns, designates it in homely fashion the Grey Mare's Tail.

Seen from the front, the Staubbach often presents the appearance of a white semi-transparent lace veil, flitting to and fro over the face of the rock, and contracting itself now and then into folds and undulations as of drapery. The occurrence of this aspect, however, depends much on the quantity of water 
being such as to project it sufficiently forward from the rock, and the condition of the atmosphere in respect of stillness; and, indeed, so volatile a phenomenon is liable to be quite changed and upset by an infinitude of circumstances-just as the centre of the earth, too, is by the casting of a stone or the rocking of a cradle. The Staubbach, however, for most part reveals its glory just when the sun is nearing the meridian; that is, a little before noon. At this particular time more especially a rainbow gilds it, which, with the snowy whiteness of the spray, is all the more impressive from the shadow of the water on the face of the rock: and so here, as everywhere, the depth of the shadow enhances the glory of the sunshine, perception itself being possible only in virtue of the circumambient void. When mists or clouds envelop the brow of the precipice, the effect on the mind is very singular; for then the waters appear, like Minerva from the brain of Jupiter, to leap ready formed direct from the sky. It was this aspect which led Wordsworth to call the Staubbach "The heaven-born waterfall."

This cascade has its winter as well as its summer moods; for, besides being behung with icicles from top to bottom, it congeals from below upwards, like an enormous stalagmite, into a pyramidal ice-mass, which rises and rises until, it is said, it attains to an altitude half its height! A footpath leads to the summit of the fall, to gratify the curious; but few attempt it. 


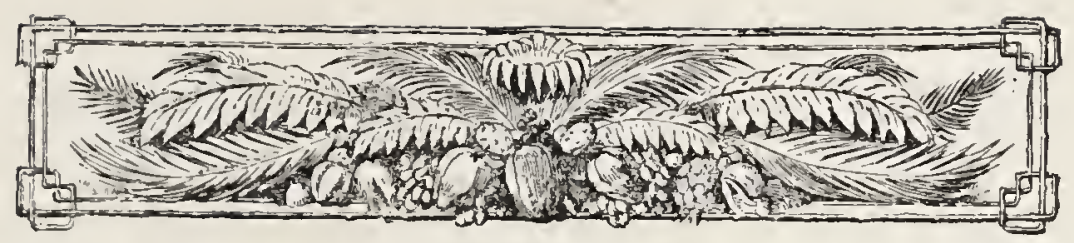

X.

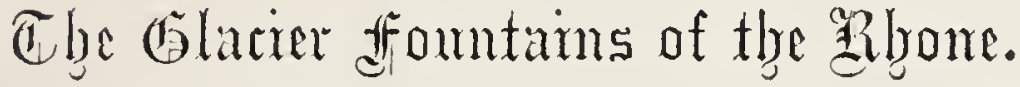

HE Rhone, which is one of the most rapid
rivers in the world, rises in a glacier
of Switzerland upwards of 20 miles in a direct line east from the Staubbach, and after a course of $66+$ miles in length and of varied character, mostly impetuous, falls by several mouths into the Mediterranean Sea at the north-eastern margin of the Gulf of Lyons. After rising at an elevation of 5726 feet, and traversing the Canton de Valais south-westward, increased by numerous affluents, it falls, by a bend northward, under precipices 8000 feet high, into the eastern extremity of the Lake of Geneva, its level above the sea diminished already to 1350 feet. Of a milk-and-water complexion at its source, it flows onward until, as it enters the lake, it is of a turbid yellow; but as it traverses its fifty miles of length without mingling, it undergoes filtration, and finally, by a chemical process which no one has expounded, issues from the western extremity clear as crystal, and of the colour of indigo - "the blue waters of the 
arrowy Rhone." It does not, however, proceed a mile beyond Geneva before it is again rendered as turbid as ever by the waters of the Arve, which here come down upon it troubled from the glaciers of Mont Blanc; and it never recovers its composure again throughout its course till its waters are merged and lost in the blue Mediterranean wave. Just where it bounds through the gorge of the Jura, and crosses the frontier of France, it used to dive suddenly under a tunnel 400 or 500 feet long, formed by overarching fragments of fallen rock, and called, at its immersion, the Loss of the Rhone; but these fragiments have been removed. It is navigable as far as Lyons, though with difficulty, on account of the current and the shifting sand-banks, and not at all but for the canals which connect it with the Mediterranean, and even the Loire, the Seine, and the Rhine.

Its fountains, and those of its affluents, are mostly in the glaciers of the Alps, and result partly from the melting of these masses at their upper or under surfaces below the line of perpetual snow, and partly from springs which percolate continually through veins in the rocks of the mountains whose upper valleys these glaciers fill. The Rhone-glacier proper, the highest source of the river, occupies a northward extending valley in the extreme north-east of the Canton de Valais, and inserted like a wedge between the Cantons of Berne and Uri, which here run southward, the one to the right of it and the other to the left. This glacier is one of the most grandly im- 
pressive in Switzerland, and fit first-parent, it has been remarked, of so lordly and majestic a river. From

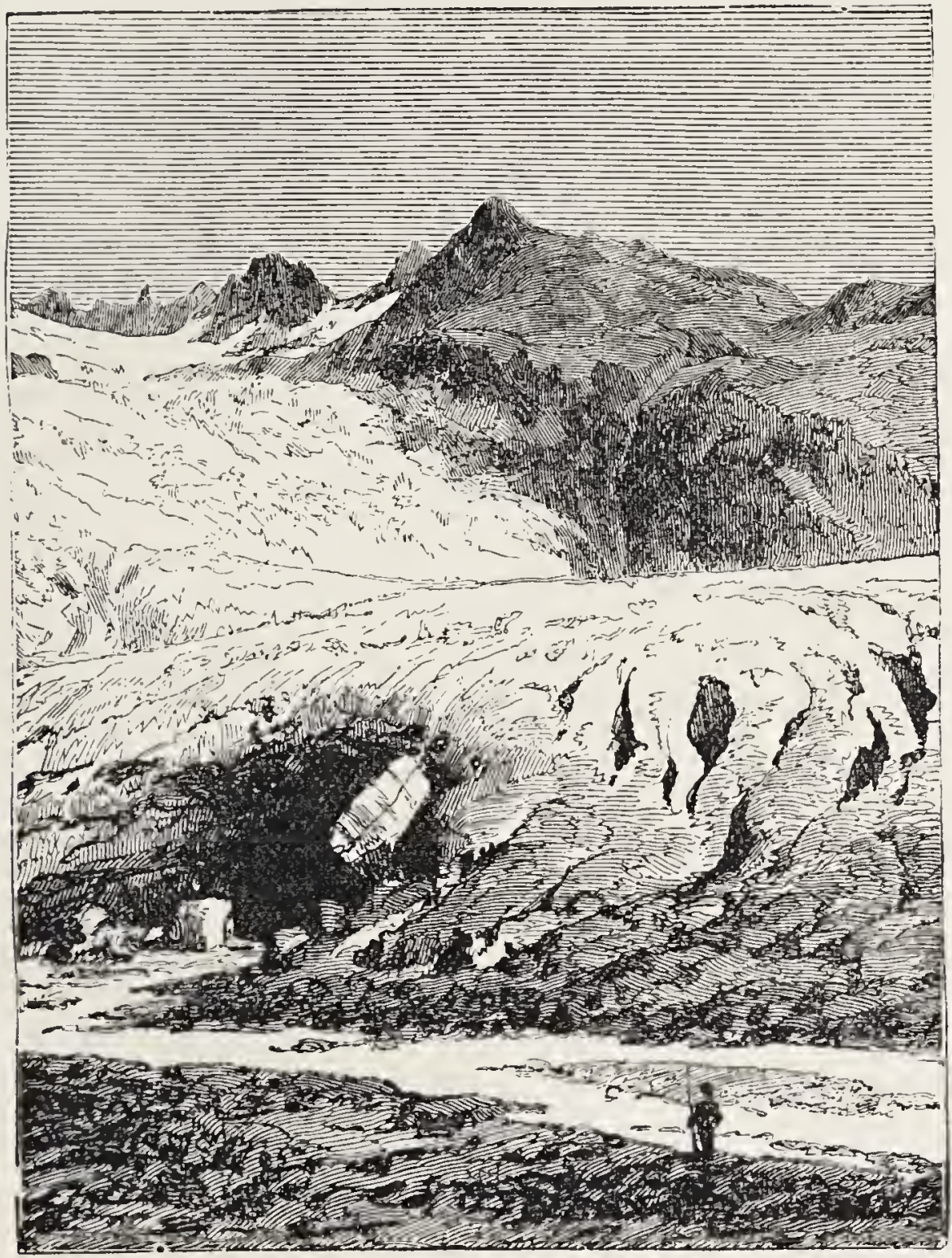

HIGHEST SOURCE OF THE RIUNE.

underneath its lower extremity the river first emerges,

a more or less huge irregular vault of ice arching it over, which seems, as you gaze into it, a deep, 
dark, receding cavern. This vault is ever chang. ing its form and aspect, and sometimes, mayhap, it collapses and falls in, blocking up the stream, which then bursts through the crevasses above, sweeps all away, and leaves a vault again. The river, as it here emerges in such flood, is greater, you at once conjecture, than the slow melting of the glacier alone can produce; and so, ascending its western. or right bank, you find, well up, a fine waterfall at play, pouring its waters down a crevasse in the glacier more than a hundred feet deep, and scattering around a cold, misty spray. The valley, the head of which the glacier fills, is called the Furca. or Fork; and the glacier looks as if it lay reposing on the strong bosom of a mountain, whose awful form guards it from above. Mount St. Gothard lies to the east of it, and east of that the source of the German Rhine-point this worth fixing in our geography once for all.

The affluents of the Rhone, equally with the Rhone itself, have, we say, their sources in Alpine glaciers; all those, at any rate, which add any considerable body of water to the main stream. Of these we shall mention only the Arveiron, which issues from the celebrated $\mathrm{Mer}$ de Glace, and loses its waters soon in those of the Arve, as these at length do in the waters of the Rhone, a mile below Geneva. The Arveiron rises three miles above Chamouni and is reached from this village by a good roar which follows the southern bank of the Arve; and. 
THE: GLACIER HOUNTAINS OF THE RHONE. 111

by a detour to the right, in a little conducts even vehicles to the source itself. The waters here, as at

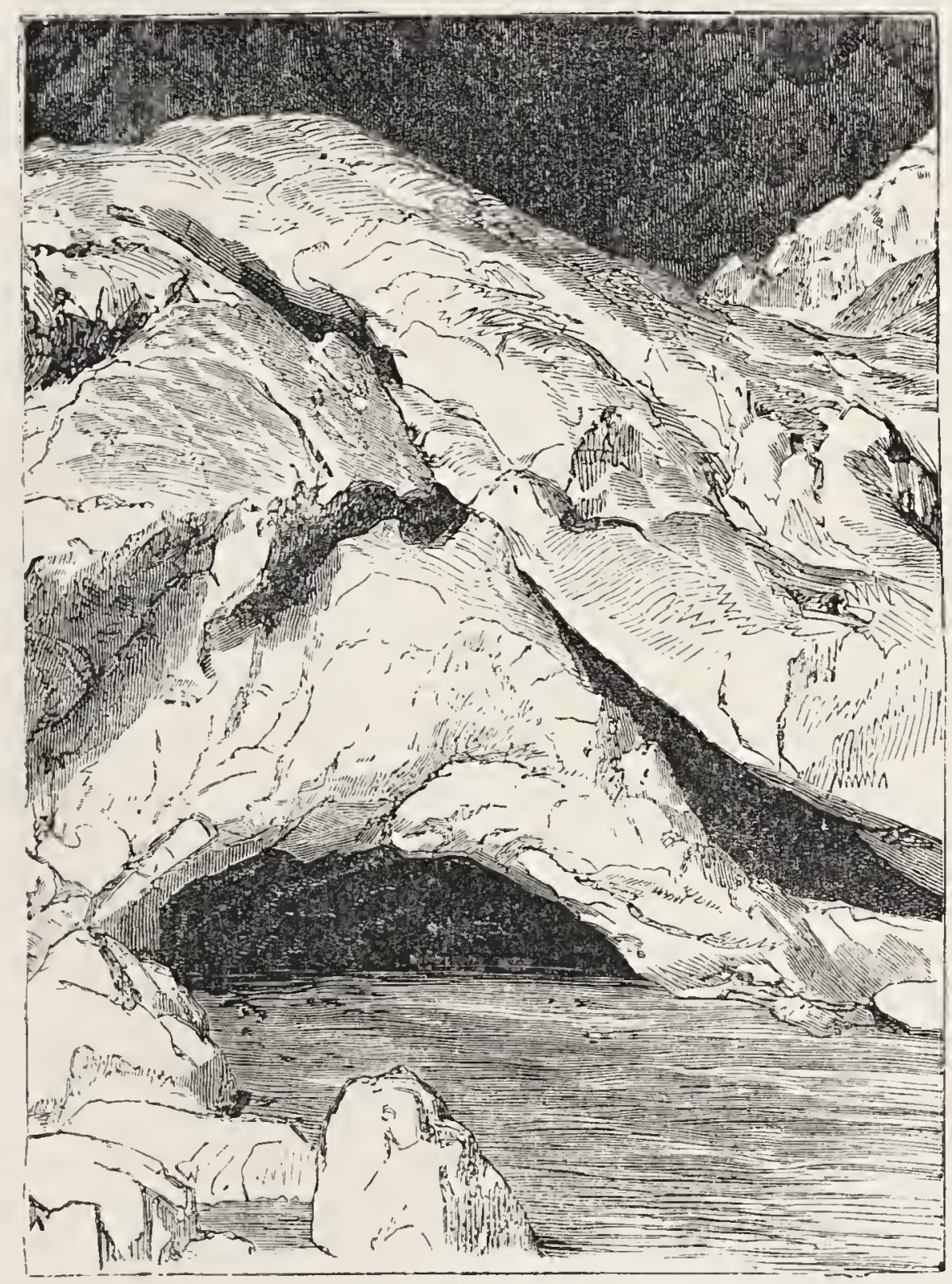

SOURCE UF THE ARVEIRON.

the Rhone glacier, are seen emerging turbir from a dark grotto or cavern under a deep-blue vault of ice, 


\section{THE GLACIER FOUNTAINS OF THE RHONE.}

which at one season you will find arching itself over the stream to a height of 100 feet, and at another depressed to 30 feet. So stable is the appearance of this arcade, that the daring or fool-hardy are not unfrequently tempted to assay expiorations; but the risks are serious, and more than one of these adventurers has paid for lis rashness with his life. This arch, composed as it is of separate, mostly large, blocks of ice, supporting each other, is not always, in the thawings and shiftings of these, in the most stable equilibrium, but so ticklishly balanced sometimes that the report of a pistol will-as at the Rhone glacier once, when two boys were buried in the ruins-bring the whole with doomsday crash about your ears. This ice-grotto is at the nether extremity of the Mer de Glace, which is here called the Glacier du Bois, that is, "Glacier of the Wood;" presumably because of the pine-forest seen to the rear of its fore-front, and now dominating it on the left. 'This glacier, like the rest, sometimes retires back the valley, and sometimes advances lower down: thirty years ago, it seems, it came short of this forest, which it has now outstripped. The scenery around is very grand;-there before you is the black unfathomed darkness of the cavern, the deep azure of the translucent vault above it, and the green pine-forest waving mysteriously on the heights beyond; while at your feet dashes the torrent of the Arveiron, tumbling away before it the bouldermasses which the glacier has borne hither from the 
mountain sides, and not resting till it has delivered every one of them, with a tenderness of its own, to the tenderer mercies of the Arve below.

It is to the melting of the ice of the glacier, we have said, the creation of these Rhone-sources is chiefly due. This melting into water-for there is a melting from snow into ice-grains, which takes place above-goes on exclusively below the snow-line, and varies with the season and the height. Agassiz found the glacier of the Aar at mid-height sweat itself down one summer ten or eleven feet, and in the month of August alone four feet; while by the end of winter it had, by simply hibernating, recovered all its wasted muscle and even waxed fat. The water which the melting creates on the surface flows partly down the crevasses with which it is everywhere slashed and pierced, and partly into the minutely-porous, spongy tissue, which composes its mass. The liquid, which thus enters above, collects beneath, where it forms and flows in a channel, to emerge, it may be, as a torrent where the glacier ends. But it is not merely by melting at its surface that the glacier contributes to augment this torrent: the walls of its cavities are corroded, so to speak, and widened both by the warmth of the spring and melted waters which pass through them, and by the currents of air, often $12^{\circ}$ above freezing, which these create in its interior. So extensive are the caverns underneath the glaciers which these causes produce, that they have been 
114 THE GLACIER Fountains of the RHoNe.

penetrated in one case from the mouth upwards to a distance of 650 feet, and been found in another to vault themselves into an ice-pillared dome canopying an area a quarter of a league square!

Two opposite phenomena result from the presence of foreign bodies-such as gravel, slate, boulder-stone -on the surface of the glacier while the melting proceeds. In one case, the presence of such bodies, by their susceptibility to the solar heat and power of imparting it to the ice below, causes depressions, or "noon pits," as they are called, on the face of the glacier; while in another, when their mass is large and impermeable to such influences, a protuberance is the result, in shape and appearance resembling a mushroom. The ice in this latter case melts away all round the boulder, leaving it high and dry; and the more the face of the glacier is depressed by the melting, the higher it appears to rise, and the slenderer the ice-column on which it rests. This latter result is due to the direct action erelong of the sun's rays on the supporting column, and the reflection thereof from the surface of the glacier itself. These protuberances are called glacier tables, and they are especially characteristic of the glacier of the Aar. From the melting which takes effect upon their columns being greatest when the sun is due south, that is, at mid-day, and therefore on their southern side, they have an inclination or dip in the main towards the meridian; nay, from the sun's rays playing upon them at different angles from 
THE GLACIER FOUNTAINS OF THE RHONE. 115 morning to evening, they become a species of dial or sun-clock, like sun-flowers, and tell by their oscillations, to a good eye, not merely the points of the compass, but actually the hours of the day. When the column becomes too slight to uphold the block,

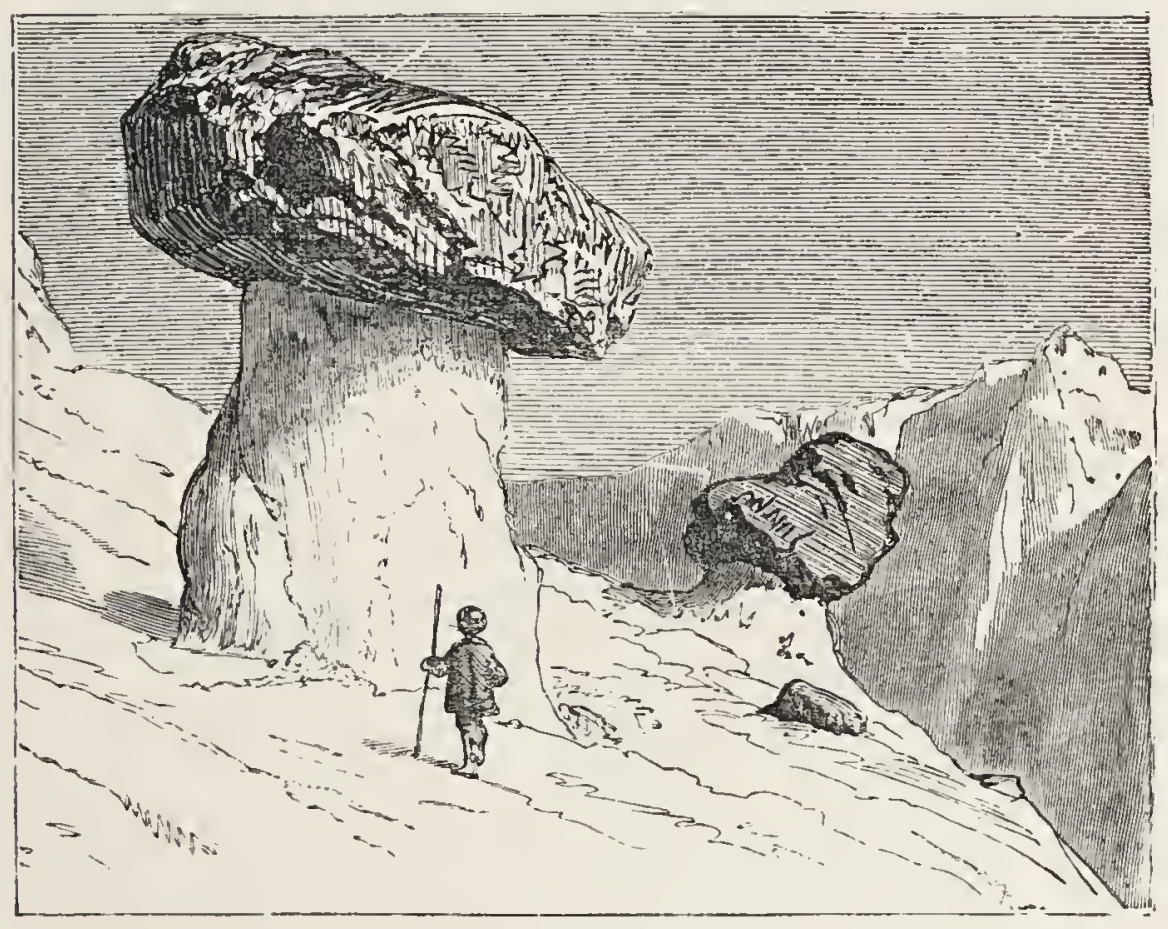

GLACIER TABLE.

so that it falls, or, as is usually the case, when the block from undue inclination slides off the pedestal, it will often hollow for itself a new bed lower down in the glacier, to be raised again on a new pillar, only however to fall anew.

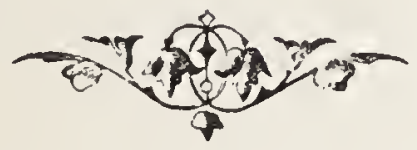




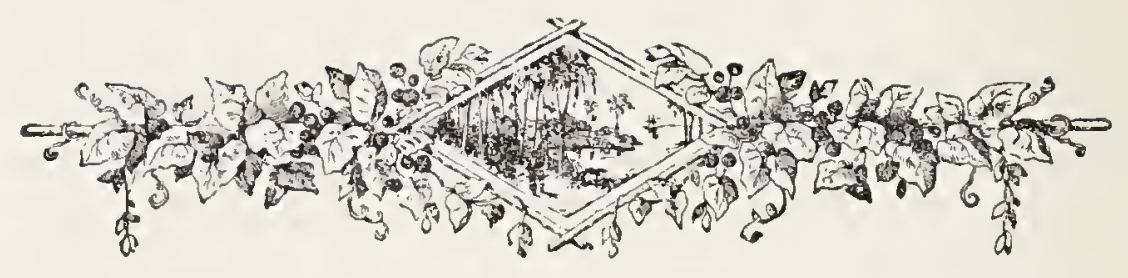

\section{XI.}

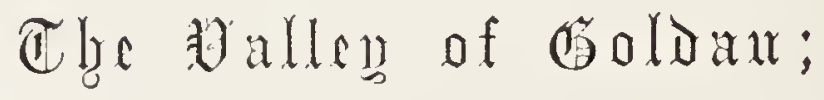

OR, THE FATAL LANDSLIP.

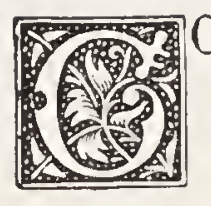

OLDAU, a town in Switzerland confined within a valley extending south-eastward from Lake Zug to Lake Lowertz, between Mount Rcssberg on the north and Mount Rigi on the south, was, along with two neighbouring villages, the scene of one of the most fatal disasters, resulting from landslip, that has occurred in the memory of man. It is fifteen miles or so east of Jucerne, and not very far from the spot where William Tell with his unerring arrow shot the tyrant Gessler. The catastrophe for which it will be long remembered in the annals of misfortune occurred at five o'clock on the evening of the 2 nd of September 1806, and it involved the instant and utter destruction of no fewer than 450 human beings. An immense layer of rock, understood, from the clifflike fracture that still remains to tell the tale, to have been nearly 3 miles long, 1000 feet broad, and 100 feet thick, loosened at length by the previous two 
days' rains percolating and washing away, or softening into a greasy condition, the earth that supported it, slid suddenly forward and came rushing down from the high brow of the Rossberg with the

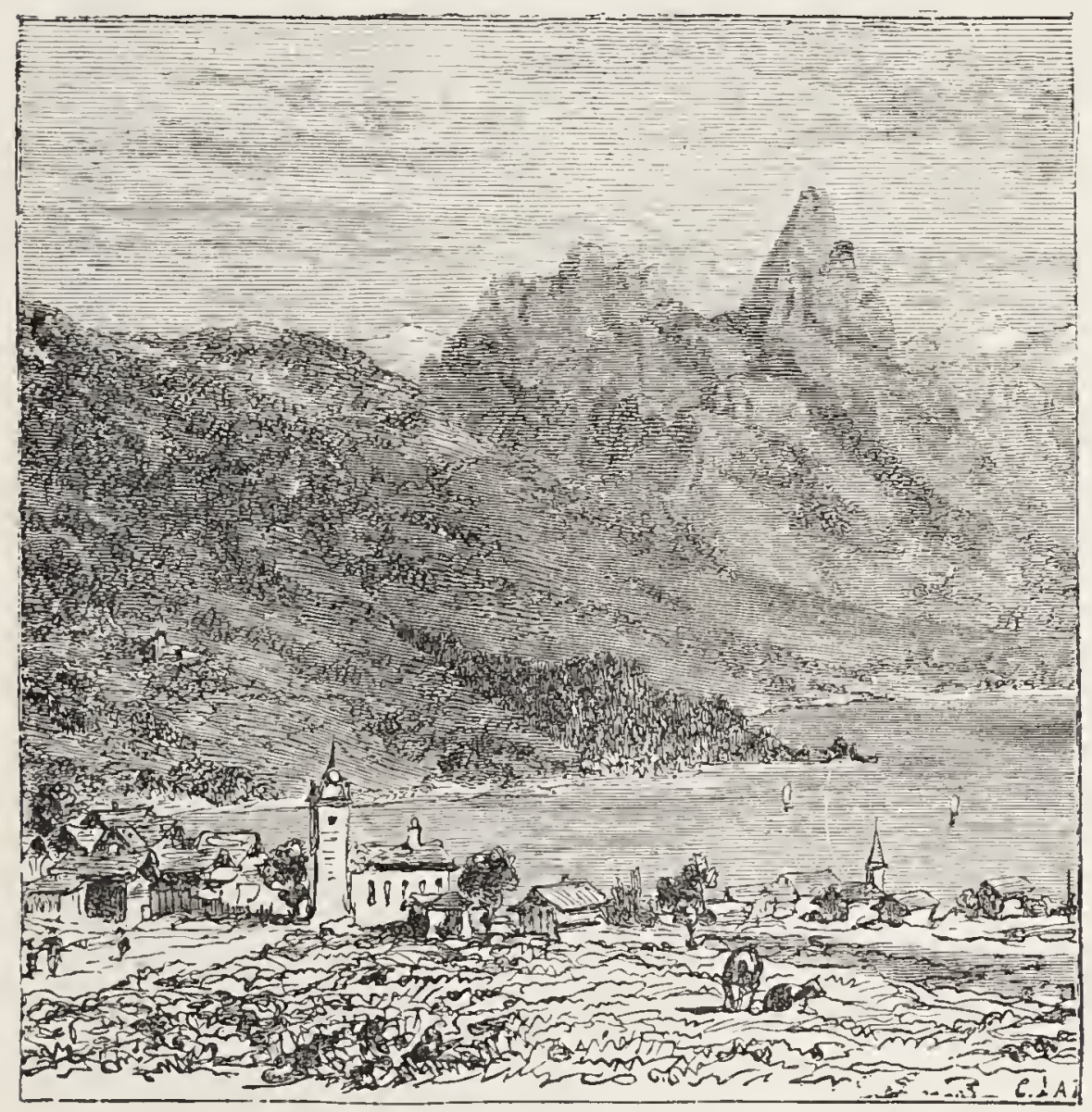

GOLUAU BEFORE THE LANUSLIP.

crash and force of an avalanche tenfold intensified, sweeping the valley from end to end as with the besom of destruction. Churches, houses, huts, with nearly all of living they held within them. were crushed and 
whirled away before it, not one stone left upon another; and the lake at the foot of the valley was in great part filled with a wreck of rocks and mud. The waters of the lake were so washed up, in conse-.

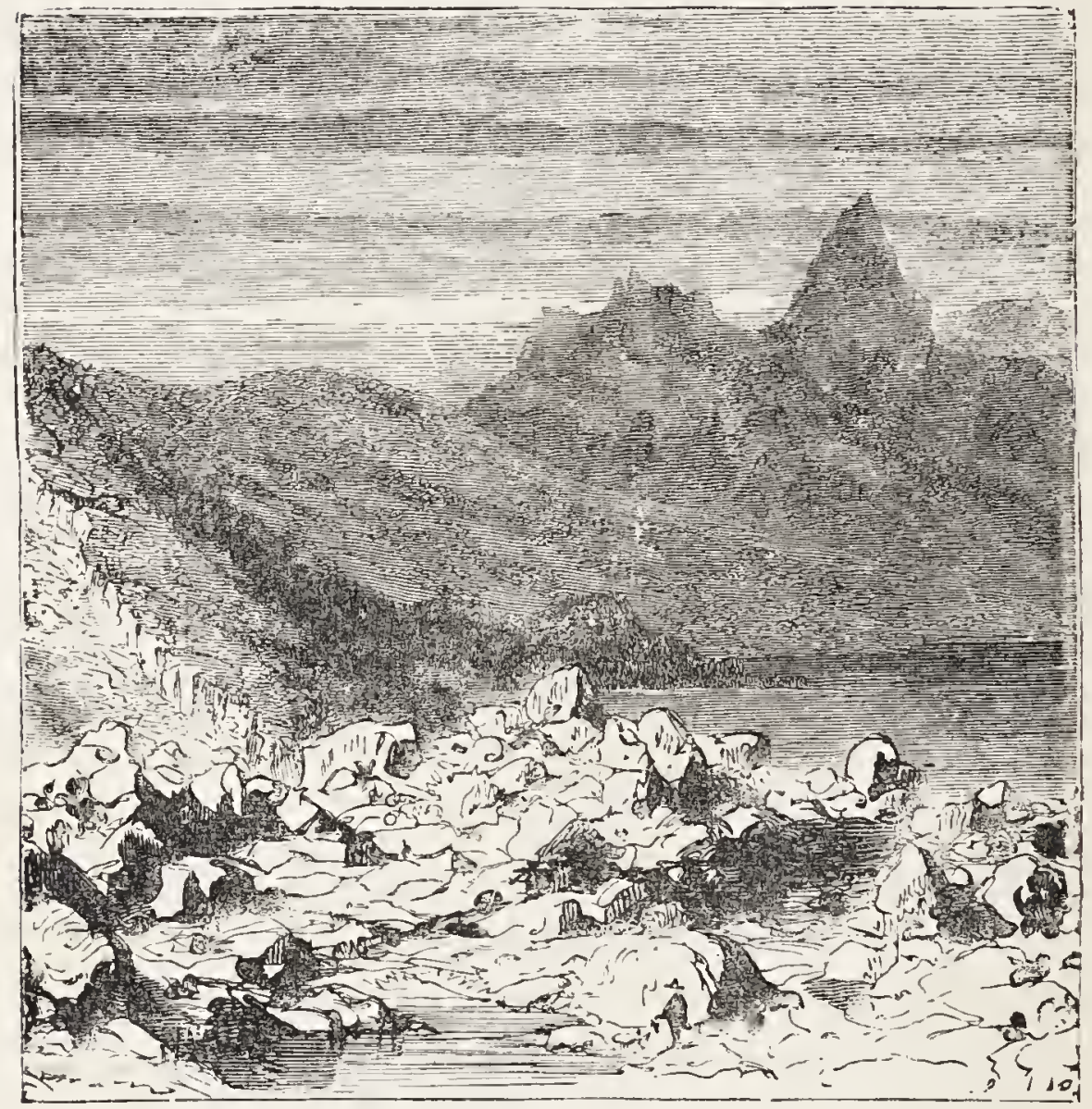

GOLDAU AFTER THE LANDSLIP.

quence, as to deluge and devastate a village at its further extremity; the earth was subjected to a shock felt across hills and valleys; and the air was darkened far and wide with clouds of dust-at the 
sight of which men's learts failed within thern. The valley up to that moment was a place of green pastures and ploughed fields, of gardens and orchards, of flocks and herds and happy homesteads; and in less than five minutes the whole lay buried under mounds of mud and fractured rock, in some parts hundreds of feet deep to this hour. And nowfrom the long deep scar on the brow of the mountain to the slope of the Rigi across the valley -it is a desolate waste of mere ruin, over which the moss and the grass-blade are here and there slowly creeping, to veil, indeed, and clothe it, but where ages shall pass away before its slopes ring as formerly to "the plough-boy's whistle and the milk-maid's song."

Not without warnings did all this sad calamity befall. An old man in the village had long predicted it would happen; and on the very day of its occurrence the mountain itself gave intimations admonitory of the impending doom. "New crevices," says Dr. Zay, an eye-witness, "were observed in the Fank of the mountain, a sort of crackling noise was heard internally, stones started out of the ground, detached fragments of rocks rolled down the mountain; and at two o'clock of the day a large rock became loose, and in falling raised a cloud of black dust." Add to this, on the same authority, that the pine-trees on the slopes were seen to reel and ominously droop; the springs dried up and gave no Water: and the birds in their terror, flew sway 
screaming. Nay, on the stroke of five, when the judgment hour had all but come, the warnings grew louder, and the mountain seemed to know and have pity, for had this last doom's-blast been heeded all might have been saved. Not more than four or five, however, believed the summons and obeyed its trumpet-call. The old man who predicted its advent was quietly smoking his pipe, when one of those who escaped came running past and pointed to the falling mountain. He looked up, observed he had time to fill his pipe yet, and lost his life under the vain delusion that the judgment would wait for him.

Nor were the villagers the only sufferers in this fearful disaster. A party of eleven tourists from Berne were traversing the valley to ascend the Rigi at the moment of the landslip. Of these, four, who were in the rear, escaped with difficulty, but the rest were swallowed up and swept away; nor, though every effort was made to recover their bodies, has the smallest relic belonging to them ever been found.

"Nothing," says Dr. Zay, "is left of Goldau but the bell which liung in its steeple, and which was found about a mile off." A chapel now stands on the site of this ill-fated village; and here the pious assemble aniually on the 2nd of September, to pray to Heaven to avert all similar calamities from themselves and their children for the future.

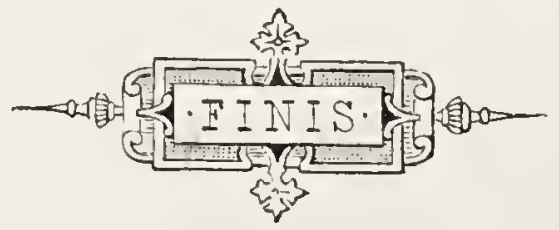




$$
\text { . }
$$



